\title{
PHOTOCHEMISTRY OF METHANE IN THE EARTH'S EARLY ATMOSPHERE
}

\author{
J.F. KASTING* \\ National Center for Atmospheric Research, P.O. Box 3000, Boulder, CA 80307 (U.S.A.)
}

\section{K.J. ZAHNLE}

Department of Astronomy and Department of Atmospheric and Oceanic Science, The University of Michigan, Ann Arbor, MI 48109 (U.S.A.)

J.C.G. WALKER

Space Physics Research Laboratory and Department of Atmospheric and Oceanic Science, The University of Michigan, Ann Arbor, MI 48109 (U.S.A.)

\section{ABSTRACT}

Kasting, J.F., Zahnle, K.J. and Walker, J.C.G., 1983. Photochemistry of methane in the Earth's early atmosphere. Precambrian Res., 20:121-148.

A detailed model is presented of methane photochemistry in the primitive terrestrial atmosphere along with speculation about its interpretation. Steady-state $\mathrm{CH}_{4}$ mixing ratios of $10^{-6}-10^{-4}$ could have been maintained by a methane source of about $10^{11} \mathrm{~cm}^{-2}$ $\mathrm{s}^{-1}$, which is comparable to the modern biogenic methane production rate. In the absence of a source, methane would have disappeared in $<10^{4}$ years, being either oxidized, or polymerized into more complex hydrocarbons. The source strength needed to maintain a steady $\mathrm{CH}_{4}$ mixing ratio and the degree to which methane could have polymerized to form higher hydrocarbons depend upon the amount of $\mathrm{CO}_{2}$ present in the early atmosphere. The dependence on $\mathrm{H}_{2}$ is much weaker. Infrared absorption by methane, and especially by other hydrocarbon species, may have supplemented the greenhouse warming due to carbon dioxide. A radiative model is needed to establish this effect quantitatively. The destruction of the methane greenhouse early in the Proterozoic may have triggered the Huronian glaciation.

These calculations also suggest that atmospheres rich in both $\mathrm{CO}_{2}$ and $\mathrm{CH}_{4}$ may be photochemically unstable with respect to conversion to CO.

\section{INTRODUCTION}

Theoretical calculations by several investigators have led to plausible models for the composition of the Earth's primitive atmosphere (Walker, 1977; Yung and McElroy, 1979; Kasting et al., 1979; Kasting and Walker, 1981; Pinto

*Now at NASA-Ames Research Center, Moffett Field, CA 94035, U.S.A. 
et al., 1980). The model atmospheres considered in these studies consist primarily of $\mathrm{N}_{2}, \mathrm{CO}_{2}$ and $\mathrm{H}_{2} \mathrm{O}$, along with smaller concentrations of $\mathrm{H}_{2}$ and $\mathrm{CO}$, and only trace amounts of $\mathrm{O}_{2}$. This type of weakly reducing early atmosphere is consistent with both the geological record and with the present understanding of volcanic emissions and the escape of hydrogen to space.

The factors controlling climate on the early Earth are less well understood. Models of stellar evolution predict that the ancient Sun was considerably less luminous than it is today (Newman and Rood, 1977). Since the Earth does not appear to have been extensively glaciated during the first half of its history (Frakes, 1979), several authors have suggested that the atmospheric greenhouse effect must have been substantially larger in the remote past. Sagan and Mullen (1972) originally proposed ammonia as the key primordial greenhouse constituent. However, calculations by Kuhn and Atreya (1979) and Kasting (1982) indicate that ammonia is photochemically unstable with respect to conversion to $\mathrm{N}_{2}$ and is, therefore, unlikely to have played a major role in warming the Earth's surface.

Carbon dioxide is a more promising candidate. Owen et al. (1979) have shown that $\mathrm{CO}_{2}$ concentrations of 100-1000 PAL (present atmospheric level) could have provided the required warming. Walker et al. (1981) have proposed a mechanism by which enhanced $\mathrm{CO}_{2}$ levels could have been maintained in the distant past. The rate of loss of $\mathrm{CO}_{2}$ through silicate weathering depends upon rainfall and is, therefore, likely to be a strong function of surface temperature. At global surface temperatures lower than today's, the $\mathrm{CO}_{2}$ loss rate should decrease and more $\mathrm{CO}_{2}$ should accumulate in the atmosphere. The Earth's climate may be effectively buffered by this mechanism, so that even relatively large decreases in solar luminosity may result in only small decreases in average surface temperature.

We suggest here, that the early greenhouse effect may have been further augmented by the presence of atmospheric methane. Donner and Ramanathan (1980) have shown that the $1.4 \mathrm{ppm}$ (parts per million) of methane in today's atmosphere contribute about $1.4 \mathrm{~K}$ to the present globally-averaged surface temperature. The absorption due to the $7.4 \mu$ band of methane increases linearly with $\mathrm{CH}_{4}$ concentration up to a mixing ratio of about $0.7 \mathrm{ppm}$, then more slowly above this level as the center of the band becomes saturated. Thus, methane could have made a modest contribution towards heating the early atmosphere if its mixing ratio was $>\sim 10^{-6}$. Perhaps more significantly, methane may also have polymerized in response to solar ultraviolet radiation, creating higher hydrocarbon compounds which should also have been absorbed in the infrared. If several of these compounds were each able to provide a small amount of heating, the combined effect could have been of major climatic significance. With this in mind, we have investigated the photochemical behavior of methane in the early atmosphere to determine how much $\mathrm{CH}_{4}$ might have been present and what types of higher hydrocarbons could have been formed. 


\section{THE MODEL}

The one-dimensional photochemical model used in this study is similar to that described by Kasting (1982), except that the focus is on hydrocarbon photochemistry rather than the photochemistry of ammonia. Diffusion equations were solved simultaneously for 22 different species: $\mathrm{O}_{3}, \mathrm{O}, \mathrm{H}_{2} \mathrm{O}, \mathrm{OH}$, $\mathrm{HO}_{2}, \mathrm{H}_{2} \mathrm{O}_{2}, \mathrm{H}, \mathrm{O}_{2}, \mathrm{H}_{2}, \mathrm{CO}_{2}, \mathrm{CO}, \mathrm{HCO}, \mathrm{H}_{2} \mathrm{CO}, \mathrm{CH}_{4}, \mathrm{C}_{2} \mathrm{H}_{6}, \mathrm{C}_{3} \mathrm{H}_{8}, \mathrm{C}_{4} \mathrm{H}_{10}, \mathrm{C}_{2} \mathrm{H}_{2}$, $\mathrm{C}_{2} \mathrm{H}_{4}, \mathrm{CH}_{3},{ }^{3} \mathrm{CH}_{2}$ and $\mathrm{C}_{2} \mathrm{H}_{5}$. Another 12 species, including $\mathrm{O}\left({ }^{1} \mathrm{D}\right),{ }^{1} \mathrm{CH}_{2}$, excited $\mathrm{C}_{2} \mathrm{H}_{2}\left(\mathrm{C}_{2} \mathrm{H}_{2}{ }^{*}\right), \mathrm{C}_{2} \mathrm{H}, \mathrm{C}_{2} \mathrm{H}_{3}, \mathrm{C}_{3} \mathrm{H}_{6}, \mathrm{C}_{4} \mathrm{H}_{8}, \mathrm{C}_{3} \mathrm{H}_{7}, \mathrm{C}_{4} \mathrm{H}_{9}, \mathrm{CH}_{3} \mathrm{CHO}, \mathrm{C}_{2} \mathrm{H}_{5} \mathrm{CHO}$ and $\mathrm{C}_{3} \mathrm{H}_{7} \mathrm{CHO}$, were assumed to be in photochemical equilibrium. The equations were integrated in time-dependent fashion until a steady-state solution was approached, which typically required 10-100 years of model time. More time was required for certain 'high CO' cases, as will be discussed later.

The altitude grid used in the model extends from 0 to $80 \mathrm{~km}$ in $1 \mathrm{~km}$ increments. The assumed boundary conditions for most species were zero flux at the ground and at $80 \mathrm{~km}$. At the top the upward fluxes of $\mathrm{CO}_{2}$ and $\mathrm{O}_{2}$ required to compensate for photodissociation were balanced by downward fluxes of $\mathrm{CO}$ and $\mathrm{O}$. Constant ground-level mixing ratios were assumed for $\mathrm{H}_{2} \mathrm{O}, \mathrm{H}_{2}$, $\mathrm{CO}_{2}$ and $\mathrm{CH}_{4}$. The tropospheric $\mathrm{H}_{2} \mathrm{O}$ mixing ratio was fixed at values ranging from $1.5 \times 10^{-2}$ at the ground to $3.8 \times 10^{-6}$ at $10 \mathrm{~km}$. Assumptions concerning temperature and eddy diffusion profiles, lightning production of $\mathrm{O}_{2}$, and rainout of $\mathrm{H}_{2} \mathrm{O}_{2}$ and $\mathrm{H}_{2} \mathrm{CO}$ were the same as in Kasting and Walker (1981).

Photolysis rates were calculated for a solar zenith angle of $57.3^{\circ}$ and then multiplied by 0.5 to approximate a diurnal average. Rayleigh scattering was treated using the method of Yung (1976). The importance of Rayleigh scattering in the context of primitive terrestrial atmospheres has been described by Kasting (1982). Its primary effect is to reduce solar ultraviolet fluxes in the lower troposphere which, for this model, means that $\mathrm{H}_{2} \mathrm{O}$ photolysis is slowed relative to photolysis of well-mixed species such as $\mathrm{CO}_{2}$.

The reaction scheme describing hydrocarbon formation is based on sequences proposed by Lasaga et al. (1971), Strobel (1973), Yung and Pinto (1978), Yung and Strobel (1980) and Allen et al. (1980). Reactions (R) and rate constants are listed in Table I.

In the anaerobic atmosphere, the oxidizing radicals $\mathrm{O}$ and $\mathrm{OH}$ are produced throughout the atmosphere by photolysis at $\lambda \leqq 2050 \AA$ of $\mathrm{CO}_{2}$ and $\mathrm{H}_{2} \mathrm{O}$ :

$\mathrm{CO}_{2}+\mathrm{h} \nu \rightarrow \mathrm{CO}+\mathrm{O}(\mathrm{R} 29) ; \mathrm{H}_{2} \mathrm{O}+\mathrm{h} \nu \rightarrow \mathrm{H}+\mathrm{OH}(\mathrm{R} 25)$.

These radicals initiate methane photochemistry in the lower atmosphere via

$\mathrm{CH}_{4}+\mathrm{OH} \rightarrow \mathrm{CH}_{3}+\mathrm{H}_{2} \mathrm{O}$ (R47) and $\mathrm{CH}_{4}+\mathrm{O} \rightarrow \mathrm{CH}_{3}+\mathrm{OH}(\mathrm{R} 48)$.

The resultant methyl radicals may react with atomic hydrogen to reform methane

$$
\mathrm{CH}_{3}+\mathrm{H}+\mathrm{M} \rightarrow \mathrm{CH}_{4}+\mathrm{M} \text { (R50), }
$$

or they can react with another $\mathrm{OH}$ or $\mathrm{O}$ radical to produce formaldehyde

$\mathrm{CH}_{3}+\mathrm{OH} \rightarrow \mathrm{H}_{2} \mathrm{CO}+\mathrm{H}_{2}$ (R51); $\mathrm{CH}_{3}+\mathrm{O} \rightarrow \mathrm{H}_{2} \mathrm{CO}+\mathrm{H}$ (R52). 


\section{TABLE I}

Reactions and rate constants

\begin{tabular}{|c|c|c|}
\hline Reaction & Rate constant $\left(\mathrm{cm}^{3} \mathrm{~s}^{-1}\right)$ & Reference \\
\hline (1) $\mathrm{H}_{2} \mathrm{O}+\mathrm{O}\left({ }^{1} \mathrm{D}\right) \rightarrow \mathrm{OH}+\mathrm{OH}$ & $2.3 \times 10^{-10}$ & JPL, 1979 \\
\hline (2) $\mathrm{H}_{2}+\mathrm{O}\left({ }^{1} \mathrm{D}\right) \rightarrow \mathrm{OH}+\mathrm{H}$ & $9.9 \times 10^{-11}$ & JPL, 1979 \\
\hline (3) $\mathrm{H}_{2}+\mathrm{O} \rightarrow \mathrm{OH}+\mathrm{H}$ & $3.0 \times 10^{-14} T \exp (-4480 / T)$ & $\begin{array}{l}\text { Hampson and Garvin, } \\
1977\end{array}$ \\
\hline (4) $\mathrm{H}_{2}+\mathrm{OH} \rightarrow \mathrm{H}_{2} \mathrm{O}$ & $1.2 \times 10^{-11} \exp (-2200 / T)$ & JPL, 1979 \\
\hline (5) $\mathrm{H}+\mathrm{O}_{3} \rightarrow \mathrm{OH}^{2}+$ & $1.4 \times 10^{-10} \exp (-470 / T)$ & JPL, 1979 \\
\hline (6) $\mathrm{H}+\mathrm{O}_{2}+\mathrm{M} \rightarrow \mathrm{HO}_{2}+\mathrm{M}$ & $5.5 \times 10^{-32}(300 / T)^{1 / 4}[M]$ & JPL, 1979 \\
\hline (7) $\mathrm{H}+\mathrm{HO}_{2} \rightarrow \mathrm{H}_{2}+\mathrm{O}_{2}$ & $4.7 \times 10^{-11}(\times 0$ & Hack et al., 1978, 1979 \\
\hline (8) $\mathrm{H}+\mathrm{HO}_{2} \rightarrow \mathrm{H}_{2} \mathrm{O}+\mathrm{O}$ & $4.7 \times 10^{-11}(\times 0$. & Hack et al., 1978,1979 \\
\hline (9) $\mathrm{H}+\mathrm{HO}_{2} \rightarrow \mathrm{OH}+\mathrm{OH}$ & $4.7 \times 10^{-11}(\times 0.69)$ & Hack et al., 1978,1979 \\
\hline (i0) $\mathrm{OH}+\mathrm{O} \rightarrow \mathrm{H}+\mathrm{O}_{2}$ & $4.0 \times 10^{-11}$ & JPL, 1979 \\
\hline (11) $\mathrm{OH}+\mathrm{HO}_{2} \rightarrow \mathrm{H}_{2} \mathrm{O}+\mathrm{O}_{2}$ & $4.0 \times 10^{-11}$ & JPL, 1979 \\
\hline (12) $\mathrm{OH}+\mathrm{O}_{3} \rightarrow \mathrm{HO}_{2}+\mathrm{O}_{2}$ & $1.6 \times 10^{-12} \exp (-940 / T)$ & JPL, 1979 \\
\hline (13) $\mathrm{HO}_{2}+\mathrm{O} \rightarrow \mathrm{OH}+\mathrm{O}_{2}$ & $3.5 \times 10^{-11}$ & JPL, 1979 \\
\hline $\begin{array}{l}\text { (14) } \mathrm{HO}_{2}+\mathrm{O}_{3} \rightarrow \mathrm{OH}+2 \mathrm{O}_{2} \\
\text { (15) } \mathrm{HO}_{2}+\mathrm{HO}_{2} \rightarrow \mathrm{H}, \mathrm{O}_{2}+\mathrm{O}^{2}\end{array}$ & $\begin{array}{l}1.1 \times 10^{-14} \exp (-580 / T) \\
2.5 \times 10^{-12}\end{array}$ & $\begin{array}{l}\text { JPL, } 1979 \\
\text { JPL, } 1979\end{array}$ \\
\hline (16) $\mathrm{H}_{2} \mathrm{O}_{2}+\mathrm{OH} \rightarrow \mathrm{HO}_{2}+\mathrm{H}_{2} \mathrm{O}$ & $1.0 \times 10^{-11} \exp (-750 / T)$ & JPL, 1979 \\
\hline (17) $\mathrm{O}+\mathrm{O}+\mathrm{M} \rightarrow \mathrm{O}_{2}$ & $2.76 \times 10^{-34} \exp (710 / T)[M]$ & $\begin{array}{l}\text { Campbell and Thrush, } \\
1967\end{array}$ \\
\hline (18) $\mathrm{O}+\mathrm{O}_{2}+\mathrm{M} \rightarrow \mathrm{O}_{3}+\mathrm{M}$ & $6.2 \times 10^{-34}(300$ & 1979 \\
\hline (19) $\mathrm{O}+\mathrm{O}_{3} \rightarrow 2 \mathrm{O}_{2}$ & $1.5 \times 10^{-11} \exp (-2218 / T)$ & JPL, 1979 \\
\hline (20) $\mathrm{OH}+\mathrm{OH} \rightarrow \mathrm{H}_{2} \mathrm{O}+\mathrm{O}$ & $1.0 \times 10^{-11} \exp (-500 / T)$ & $\begin{array}{l}\text { Hampson and Garvin, } \\
1977\end{array}$ \\
\hline (21) $\mathrm{O}\left({ }^{1} \mathrm{D}\right)+\mathrm{N}_{2} \rightarrow \mathrm{O}+\mathrm{N}_{2}$ & $2.0 \times 10^{-11} \exp (-107 / T)$ & JPL, 1979 \\
\hline (22) $\mathrm{O}\left({ }^{\prime} \mathrm{D}\right)+\mathrm{O}_{2} \rightarrow \mathrm{O}+\mathrm{O}_{2}$ & $2.9 \times 10^{-11} \exp (-67 / T)$ & $\mathrm{JPL}, 1979$ \\
\hline $\begin{aligned}(23) \mathrm{O}_{2}+\mathrm{h} \nu & \rightarrow \mathrm{O}_{2}+\mathrm{O}\left({ }^{1} \mathrm{D}\right) \\
\text { (24) } & \rightarrow \mathrm{O}+\mathrm{O}\end{aligned}$ & $\mathrm{J}_{\mathrm{O}_{2}}$ & Kasting et al., 1979 \\
\hline (25) $\mathrm{H}_{2} \mathrm{O}+\mathrm{h} v \rightarrow \mathrm{H}+\mathrm{OH}$ & $\mathrm{J}_{\mathrm{H}_{2} \mathrm{O}}$ & g et al., 1979 \\
\hline $\begin{aligned}(26) \mathrm{O}_{3}+\mathrm{h} \nu & \rightarrow \mathrm{O}_{2}+\mathrm{O}\left({ }^{1} \mathrm{D}\right) \\
(27) & \rightarrow \mathrm{O}_{2}+\mathrm{O}\end{aligned}$ & & Kast \\
\hline (28) $\mathrm{H}_{2} \mathrm{O}_{2}+\mathrm{h} \nu \rightarrow \mathrm{OH}+\mathrm{OH}$ & & 979 \\
\hline (29) $\mathrm{CO}_{2}+\mathrm{h} \nu \rightarrow \mathrm{CO}+\mathrm{O}$ & & Kas \\
\hline$(30) \mathrm{CO}+\mathrm{OH} \rightarrow \mathrm{CO}_{2}$ & $\begin{array}{l}6.0 \times 10^{-13}[0.25+A[\mathrm{M}]] / \\
{[1+A[\mathrm{M}]]^{\mathrm{a}}}\end{array}$ & $\begin{array}{l}\text { Hampson and Garvin, } \\
1977\end{array}$ \\
\hline (31) $\mathrm{CO}+\mathrm{O}+\mathrm{M} \rightarrow \mathrm{CO}_{3}+\mathrm{M}$ & $6.5 \times 10^{-33} \exp (-2180 / T)[\mathrm{M}]$ & $\begin{array}{l}\text { Hampson and Garvin, } \\
1977\end{array}$ \\
\hline (32) $\mathrm{H}+\mathrm{CO}+\mathrm{M} \rightarrow \mathrm{HCO}+\mathrm{M}$ & $2.0 \times 10^{-33} \exp ($ & Baulch et al., 1976 \\
\hline (33) $\mathrm{H}+\mathrm{HCO} \rightarrow \mathrm{H}_{2}$ & $1.2 \times 1$ & Hochanadel et al., 1980 \\
\hline (34) $\mathrm{HCO}+\mathrm{HCO} \rightarrow \mathrm{H}_{2} \mathrm{CO}+\mathrm{CO}$ & $2.3 \times 10^{-11}$ & Hochanadel et al., 1980 \\
\hline (35) $\mathrm{OH}+\mathrm{HCO} \rightarrow \mathrm{H}_{2} \mathrm{O}+\mathrm{CO}$ & $5.0 \times 10^{-11}$ & Baulch et al., 1976 \\
\hline (36) $\mathrm{O}+\mathrm{HCO} \rightarrow \mathrm{H}+\mathrm{CO}_{2}$ & 1. & $\begin{array}{l}\text { Hampson and Garvin, } \\
1977\end{array}$ \\
\hline (37) $\mathrm{O}+\mathrm{HCO} \rightarrow \mathrm{OH}+\mathrm{CO}$ & $1.0 \times 10^{-10}$ & $\begin{array}{l}\text { Hampson and Garvin, } \\
1977\end{array}$ \\
\hline $\begin{aligned}(38) \mathrm{H}_{2} \mathrm{CO}+\mathrm{h} \nu & \rightarrow \mathrm{H}_{2}+\mathrm{CO} \\
\text { (39) } & \rightarrow \mathrm{HCO}+\mathrm{H}\end{aligned}$ & $\mathrm{J}_{\mathrm{H}_{2} \mathrm{CO}}$ & Calvert et al., 1972 \\
\hline $\begin{array}{l}\text { (40) } \mathrm{HCO}+\mathrm{h} \nu \rightarrow \mathrm{H}+\mathrm{CO} \\
\text { (41) } \mathrm{H}_{2} \mathrm{CO}+\mathrm{H} \rightarrow \mathrm{H}_{2}+\mathrm{HCO}\end{array}$ & $\begin{array}{l}1.0 \times 10^{-2} \mathrm{~s}^{-1} \\
2.8 \times 10^{-11} \text { ex }\end{array}$ & $\begin{array}{l}\text { Pinto et al., } 1981 \\
\text { JPL, } 1979\end{array}$ \\
\hline
\end{tabular}




\begin{tabular}{|c|c|c|}
\hline Reaction & Rate constant $\left(\mathrm{cm}^{3} \mathrm{~s}^{-1}\right)$ & Reference \\
\hline $\mathrm{h} \nu \rightarrow \mathrm{CO}+\mathrm{O}\left({ }^{1} \mathrm{D}\right)$ & & Kasting et al., 1979 \\
\hline & $\times 10^{-33} \exp (375 / T)[\mathrm{M}]$ & Liu and Donahue, 1974 \\
\hline 44) $\mathrm{HCO}+\mathrm{O}_{2} \rightarrow \mathrm{HO}_{2}+\mathrm{CO}$ & $4.0 \times 10^{-12}$ & Reilly et al., 1978 \\
\hline (45) $\mathrm{H}_{2} \mathrm{CO}+\mathrm{OH} \rightarrow \mathrm{H}_{2} \mathrm{O}+\mathrm{HCO}$ & $1.7 \times 10^{-11} \exp (-100 / T)$ & JPL, 1979 \\
\hline (46) $\mathrm{H}+\mathrm{OH}+\mathrm{N}$ & $6.1 \times 10^{-26} / T^{2}[$ & $\begin{array}{l}\text { Hampson and Garvin, } \\
1977\end{array}$ \\
\hline 47) $\mathrm{CH}_{4}+\mathrm{OH} \rightarrow \mathrm{CH}_{3}+\mathrm{H}_{2} \mathrm{O}$ & $2.4 \times 10^{-12} \exp (-1710 / T)$ & JPL, 1979 \\
\hline (48) $\mathrm{CH}_{4}+$ & $2.3 \times 10^{-11} \exp$ & $\begin{array}{l}\text { Hampson and Garvin, } \\
1977^{\mathrm{m}}\end{array}$ \\
\hline (49) $\mathrm{CH}_{4}+\mathrm{O}\left({ }^{1} \mathrm{D}\right)+\mathrm{CH}_{3}+\mathrm{OH}$ & $1.3 \times 10^{-10}$ & JPL, 1979 \\
\hline (50) $\mathrm{CH}_{3}+\mathrm{H}+\mathrm{M} \rightarrow \mathrm{CH}_{4}+\mathrm{M}$ & $\begin{array}{l}3.3 \times 10^{-10} /\left[1+1 /\left(2 \times 10^{-19}\right.\right. \\
[\mathrm{M}])]\end{array}$ & Cheng and Yeh, 1977 \\
\hline (51) $\mathrm{CH}_{3}+\mathrm{OH} \rightarrow \mathrm{H}_{2} \mathrm{CO}+\mathrm{H}_{2}$ & $1.0 \times 10^{-10}$ & Estin \\
\hline (52) $\mathrm{CH}_{3}+\mathrm{O} \rightarrow \mathrm{H}_{2} \mathrm{CO}+\mathrm{H}$ & $1.0 \times 10^{-10}$ & $\begin{array}{l}\text { Hampson and Garvin, } \\
1977\end{array}$ \\
\hline (53) $\mathrm{CH}_{3}+\mathrm{CH}_{3}+\mathrm{M} \rightarrow \mathrm{C}_{2} \mathrm{H}_{6}+\mathrm{M}$ & $\begin{array}{l}\operatorname{Min}\left[5.5 \times 10^{-11} ; 1.7 \times 10^{-17}\right. \\
\left.T^{-2.3}[\mathrm{M}]\right]\end{array}$ & $\begin{array}{l}\text { Van den Bergh, 1976; } \\
\text { Troe, } 1977\end{array}$ \\
\hline (54) $\mathrm{C}_{2} \mathrm{H}_{6}+\mathrm{OH} \rightarrow \mathrm{C}_{2} \mathrm{H}_{5}+\mathrm{H}_{2} \mathrm{O}$ & $1.86 \times 10^{-11} \exp (-1230 / T)$ & $\begin{array}{l}\text { Hampson and Garvin, } \\
1977\end{array}$ \\
\hline (55) $\mathrm{C}_{2} \mathrm{H}_{6}+\mathrm{O} \rightarrow \mathrm{C}_{2} \mathrm{H}_{5}+\mathrm{OH}$ & $4.1 \times 10^{-11} \exp (-3200 / T)$ & $\begin{array}{l}\text { Hampson and Garvin, } \\
1977\end{array}$ \\
\hline (56) $\mathrm{C}_{2} \mathrm{H}_{6}+\mathrm{O}\left({ }^{1} \mathrm{D}\right) \rightarrow \mathrm{C}_{2} \mathrm{H}_{5}+\mathrm{OH}$ & $1.3 \times 10^{-10}$ & Estimated ${ }^{c}$ \\
\hline (57) $\mathrm{C}_{2} \mathrm{H}_{5}+\mathrm{H} \rightarrow \mathrm{CH}_{3}+\mathrm{CH}_{3}$ & $\begin{array}{l}\operatorname{Min}\left[1.8 \times 10^{-10} \exp (-435 / T)\right. \\
\left.\quad 1.0 \times 10^{-20} T^{-3.3}[\mathrm{M}]\right]\end{array}$ & Teng and Jones, 1972 \\
\hline (58) $\mathrm{C}_{2} \mathrm{H}_{5}+\mathrm{OH} \rightarrow \mathrm{CH}_{3} \mathrm{CHO}+\mathrm{H}_{2}$ & $1.0 \times 10^{-10}$ & Estimated $^{\mathrm{b}}$ \\
\hline (59) $\mathrm{C}_{2} \mathrm{H}_{5}+\mathrm{O} \rightarrow \mathrm{CH}_{3} \mathrm{CHO}+\mathrm{H}$ & $1.0 \times 10^{-10}$ & Estimated $^{\mathrm{b}}$ \\
\hline (60) $\mathrm{C}_{2} \mathrm{H}_{5}+\mathrm{CH}_{3}+\mathrm{M} \rightarrow \mathrm{C}_{3} \mathrm{H}_{8}+\mathrm{M}$ & $(=\mathrm{R} 53)$ & Benson, 1964 \\
\hline $\begin{array}{l}\text { (61) } \begin{array}{l}\mathrm{C}_{2} \mathrm{H}_{5} \\
+\mathrm{M}\end{array} \\
+\mathrm{C}_{2} \mathrm{H}_{5}+\mathrm{M} \rightarrow \mathrm{C}_{4} \mathrm{H}_{10}\end{array}$ & $(=\mathrm{R} 53)$ & Benson, 1964 \\
\hline (62) $\mathrm{CH}_{3} \mathrm{CHO}+\mathrm{h} \nu \rightarrow \mathrm{CH}_{3}+\mathrm{HCO}$ & $4.2 \times 10^{-5} \mathrm{~s}^{-1}$ & jian et al., 1974 \\
\hline $\mathrm{H}_{2} \mathrm{O}$ & $1.8 \times 10^{-11} \exp$ & $\mathrm{d}^{\mathrm{d}}$ \\
\hline (64) $\mathrm{C}_{3} \mathrm{H}_{3}+\mathrm{O} \rightarrow \mathrm{C}_{3} \mathrm{H}_{7}+\mathrm{OH}$ & $\begin{array}{r}1.6 \times 10^{-11} \exp (-2900 / T) \\
2.2 \times 10^{-11} \exp (-2250 / T)\end{array}$ & $\begin{array}{l}\text { Hampson and Garvin, } \\
1977\end{array}$ \\
\hline (65) $\mathrm{C}_{3} \mathrm{H}_{3}+\mathrm{O}\left({ }^{1} \mathrm{D}\right) \rightarrow \mathrm{C}_{3} \mathrm{H}_{7}+\mathrm{OH}$ & $1.3 \times 10^{-10}$ & Estimated $^{\mathrm{c}}$ \\
\hline (66) $\mathrm{C}_{3} \mathrm{H}_{7}+\mathrm{H} \rightarrow \mathrm{CH}_{3}+\mathrm{C}_{2} \mathrm{H}_{5}$ & $(=\mathrm{R} 57)$ & Estimated \\
\hline (67) $\mathrm{C}_{3} \mathrm{H}_{7}+\mathrm{OH} \rightarrow \mathrm{C}_{2} \mathrm{H}_{5} \mathrm{CHO}+\mathrm{H}_{2}$ & $1.0 \times 10^{-10}$ & Estimated ${ }^{b}$ \\
\hline (68) $\mathrm{C}_{3} \mathrm{H},+\mathrm{O} \rightarrow \mathrm{C}_{2} \mathrm{H}_{5} \mathrm{CHO}+\mathrm{H}$ & $1.0 \times 10^{-10}$ & Estimated ${ }^{b}$ \\
\hline 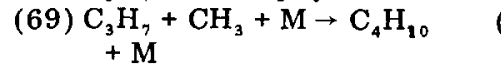 & $(=\mathrm{R} 53)$ & Benson, 1964 \\
\hline $\begin{array}{l}(70) \mathrm{C}_{2} \mathrm{H}_{5} \mathrm{CHO}+\mathrm{h} \nu \rightarrow \mathrm{C}_{2} \mathrm{H}_{3} \\
+\mathrm{HCO}\end{array}$ & $4.2 \times 10^{-5} \mathrm{~s}^{-1}$ & Estimated $^{\mathbf{e}}$ \\
\hline (71) $\mathrm{C}_{4} \mathrm{H}_{10}+\mathrm{OH} \rightarrow \mathrm{C}_{4} \mathrm{H}_{9}+\mathrm{H}_{2} \mathrm{O}$ & $1.76 \times 10^{-11} \exp (-560 / T)$ & $\begin{array}{l}\text { Hampson and Garvin, } \\
1977\end{array}$ \\
\hline (72) $\mathrm{C}_{4} \mathrm{H}_{10}+\mathrm{O} \rightarrow \mathrm{C}_{4} \mathrm{H}_{9}+\mathrm{OH}$ & $\begin{array}{r}1.6 \times 10^{-11} \exp (-2900 / T) \\
4.4 \times 10^{-11} \exp (-2250 / T)\end{array}$ & $\begin{array}{l}\text { Hampson and Garvin, } \\
1977\end{array}$ \\
\hline$(73) \mathrm{C}_{4} \mathrm{H}_{10}+\mathrm{O}\left({ }^{1} \mathrm{D}\right) \rightarrow$ & $1.3 \times 10^{-10}$ & Estimated ${ }^{c}$ \\
\hline (74) $\mathrm{C}_{4} \mathrm{H}_{9}+\mathrm{H} \rightarrow \mathrm{C}_{2} \mathrm{H}_{5}+\mathrm{C}_{2} \mathrm{H}_{5}$ & $(=0.5 \times \mathrm{R} 57)$ & Estimated \\
\hline $\begin{array}{l}\text { (75) } \mathrm{C}_{4} \mathrm{H}_{9}+\mathrm{H} \rightarrow \mathrm{C}_{3} \mathrm{H}_{7}+\mathrm{CH}_{3} \\
\text { (76) } \mathrm{C}_{4} \mathrm{H}_{6}+\mathrm{OH} \rightarrow \mathrm{C}_{3} \mathrm{H}_{7} \mathrm{CHO}+\mathrm{H}_{2}\end{array}$ & $\begin{array}{l}(=0.5 \times \mathbf{R 5 7}) \\
1.0 \times 10^{-10}\end{array}$ & $\begin{array}{l}\text { Estimated } \\
\text { Estimated }^{\mathbf{b}}\end{array}$ \\
\hline
\end{tabular}


Table I (continued)

\begin{tabular}{|c|c|c|}
\hline Reaction & Rate constant $\left(\mathrm{cm}^{3} \mathrm{~s}^{-1}\right)$ & Reference \\
\hline (77) $\mathrm{C}_{4} \mathrm{H}_{9}+\mathrm{O} \rightarrow \mathrm{C}_{3} \mathrm{H}_{7} \mathrm{CHO}+\mathrm{H}$ & $1.0 \times 10^{-10}$ & Estimated ${ }^{\mathbf{b}}$ \\
\hline $\begin{array}{c}(78) \mathrm{C}_{3} \mathrm{H}, \mathrm{CHO}+\mathrm{h} \nu \rightarrow \mathrm{C}_{3} \mathrm{H}_{7} \\
+\mathrm{HCO}\end{array}$ & $4.2 \times 10^{-5} \mathrm{~s}^{-1}$ & Estimated $^{\mathrm{e}}$ \\
\hline $\begin{array}{l}\text { (79) } \mathrm{CH}_{4}+\mathrm{h} \nu \rightarrow{ }^{1} \mathrm{CH}_{2}+\mathrm{H}_{2} \\
\text { (80) } \mathrm{C}_{2} \mathrm{H}_{6}+\mathrm{h} \nu \rightarrow \mathrm{C}_{2} \mathrm{H}_{2}+2 \mathrm{H}_{2}\end{array}$ & $\begin{array}{l}\mathrm{J}_{\mathrm{CH}_{4}} \\
\mathrm{~J}_{\mathrm{C}_{2} \mathrm{H}_{6}}\end{array}$ & $\begin{array}{l}\text { Mount et al., } 1977 \\
\text { Mount and Moos, } 1978 \\
\text { Strobel } 1973\end{array}$ \\
\hline$\rightarrow \mathrm{C}_{2} \mathrm{H}_{4}+2 \mathrm{H}$ & & \\
\hline (82) $\rightarrow \mathrm{CH}_{4}+{ }^{1} \mathrm{CH}_{2}$ & & \\
\hline (83) $\mathrm{C}_{3} \mathrm{H}_{6}+\mathrm{h} \nu \rightarrow \mathrm{C}_{3} \mathrm{H}_{6}+\mathrm{H}_{2}$ & $\mathrm{~J}_{\mathrm{C}_{3} \mathrm{H}_{8}}(\times 0.4)^{\mathrm{T}}$ & $\begin{array}{l}\text { Okabe and McNesby, } \\
1962\end{array}$ \\
\hline$\rightarrow \mathrm{C}_{2} \mathrm{H}_{4}+\mathrm{CH}_{4}$ & $(\times 0.3)$ & Calvert and Pitts, 1966 \\
\hline$\rightarrow \mathrm{CH}_{3}+\mathrm{C}_{2} \mathrm{H}_{5}$ & $(\times 0.3)$ & \\
\hline (86) $\mathrm{C}_{4} \mathrm{H}_{10}+\mathrm{h} \nu \rightarrow \mathrm{C}_{4} \mathrm{H}_{4}+\mathrm{H}_{2}$ & $\mathrm{~J}_{\mathrm{C}_{4} \mathrm{H}_{10}}(\times 0.3)^{\mathrm{f}}$ & $\begin{array}{l}\text { Okabe and Becker, } \\
1963\end{array}$ \\
\hline$\rightarrow 2 \mathrm{C}_{2} \mathrm{H}_{4}+\mathrm{H}_{2}$ & $(\times 0.16)$ & Calvert and Pitts, 1966 \\
\hline $\begin{array}{l}\rightarrow \mathrm{C}_{3} \mathrm{H}_{6}+\mathrm{CH}_{3} \\
\quad+\mathrm{H}\end{array}$ & $(\times 0.07)$ & \\
\hline $\begin{array}{l}\rightarrow \mathrm{C}_{2} \mathrm{H}_{6}+\mathrm{C}_{2} \mathrm{H}_{2} \\
\quad+\mathrm{H}_{2}\end{array}$ & $(\times 0.10)$ & \\
\hline$\rightarrow \mathrm{CH}_{3}+\mathrm{C}_{3} \mathrm{H}_{7}$ & $(\times 0.25)$ & \\
\hline (91) $\quad \rightarrow 2 \mathrm{C}_{2} \mathrm{H}_{5}$ & $(\times 0.12)$ & \\
\hline (92) $\mathrm{C}_{2} \mathrm{H}_{4}+\mathrm{h} \nu \rightarrow \mathrm{C}_{2} \mathrm{H}_{2}+\mathrm{H}_{2}$ & $\mathrm{~J}_{\mathrm{C}_{2} \mathrm{H}_{4}}$ & $\begin{array}{l}\text { Zelikoff and Watanabe, } \\
1953\end{array}$ \\
\hline$\rightarrow \mathrm{C}_{2} \mathrm{H}_{2}+2 \mathrm{H}$ & & Strobel, 1973 \\
\hline $\begin{array}{l}\text { (94) } \mathrm{C}_{3} \mathrm{H}_{6}+\mathrm{h} \nu \rightarrow \mathrm{C}_{2} \mathrm{H}_{2}+\mathrm{CH}_{3}+\mathrm{H} \\
\text { (95) } \mathrm{CH}_{3}+\mathrm{h} \nu \rightarrow \mathrm{C} \mathrm{H}_{2}+\mathrm{C}_{2} \mathrm{H}\end{array}$ & $\begin{aligned}( & \left.=J_{C_{2}} H_{4}\right) \\
( & \left.=J_{C} H\right)\end{aligned}$ & $\begin{array}{l}\text { Estimated } \\
\text { Estimated }\end{array}$ \\
\hline $\begin{array}{c}+\mathrm{H} \\
+\mathrm{H}\end{array}$ & 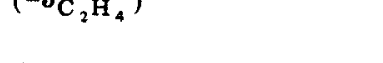 & Estimated \\
\hline (96) $\mathrm{C}_{2} \mathrm{H}_{2}+\mathrm{h} \nu \rightarrow \mathrm{C}_{2} \mathrm{H}_{2} *$ & $\mathrm{~J}_{\mathrm{C}_{2} \mathrm{H}_{2}}$ & $\begin{array}{l}\text { Nakayama and } \\
\text { Watanabe, } 1964\end{array}$ \\
\hline (97) $\mathrm{C}_{2} \mathrm{H}_{2} * \rightarrow \mathrm{C}_{2} \mathrm{H}_{2}+\mathrm{h} v$ & $3.0 \times 10^{5} \mathrm{~s}^{-1}$ & $\begin{array}{l}\text { Becker et al., 1971; } \\
\text { Stief et al., } 1965\end{array}$ \\
\hline (98) $\mathrm{C}_{2} \mathrm{H}_{2}^{*} \rightarrow \mathrm{C}_{2} \mathrm{H}+\mathrm{H}$ & $1.0 \times 10^{5} \mathrm{~s}^{-1}$ & $\begin{array}{l}\text { Takita et al., 1968, } 1969 \\
\text { Strobel, } 1973\end{array}$ \\
\hline (99) $\mathrm{C}_{2} \mathrm{H}_{2} *+\mathrm{N}_{2} \rightarrow \mathrm{C}_{2} \mathrm{H}_{2}+\mathrm{N}_{2}$ & $4.0 \times 10^{-11}$ & Estimated ${ }^{\mathrm{g}}$ \\
\hline (100) $\mathrm{C}_{2} \mathrm{H}_{2}^{*}+\mathrm{O}_{2} \rightarrow 2 \mathrm{HCO}$ & $1.0 \times 10^{-10}$ & Estimated $^{\mathrm{h}}$ \\
\hline (101) ${ }^{1} \mathrm{CH}_{2}+\mathrm{H}_{2} \rightarrow \mathrm{CH}_{3}+\mathrm{H}$ & $7.0 \times 10^{-12}$ & Braun et al., 1970 \\
\hline$(102)^{1} \mathrm{CH}_{2}+\mathrm{CH}_{4} \rightarrow \mathrm{CH}_{3}+\mathrm{CH}_{3}$ & $1.9 \times 10^{-12}$ & Braun et al., 1970 \\
\hline$(103)^{i} \mathrm{CH}_{2}+\mathrm{O}_{2} \rightarrow \mathrm{H}_{2} \mathrm{CO}+\mathrm{O}$ & $3.0 \times 10^{-11}$ & Laufer and Bass, 1974 \\
\hline (104) ${ }^{1} \mathrm{CH}_{2}+\mathrm{N}_{2} \rightarrow{ }^{3} \mathrm{CH}_{2}+\mathrm{N}_{2}$ & $5.0 \times 10^{-13}$ & Bell, 1971 \\
\hline$(105)^{3} \mathrm{CH}_{2}+\mathrm{H}_{2} \rightarrow \mathrm{CH}_{3}+\mathrm{H}$ & $5.0 \times 10^{-14}$ & Braun et al., 1970 \\
\hline (106) ${ }^{3} \mathrm{CH}_{2}+\mathrm{CH}_{4} \rightarrow \mathrm{CH}_{3}+\mathrm{CH}_{3}$ & $5.0 \times 10^{-14}$ & Braun et al., 1970 \\
\hline$(107)^{3} \mathrm{CH}_{2}+\mathrm{O}_{2} \rightarrow \mathrm{H}_{2} \mathrm{CO}+\mathrm{O}$ & $1.5 \times 10^{-12}$ & Laufer and Bass, 1974 \\
\hline (108) ${ }^{3} \mathrm{CH}_{2}+{ }^{3} \mathrm{CH}_{2} \rightarrow \mathrm{C}_{2} \mathrm{H}_{2}+2 \mathrm{H}$ & $5.3 \times 10^{-11}$ & $\begin{array}{l}\text { Russell and Rowland, } \\
1979\end{array}$ \\
\hline$(109){ }^{3} \mathrm{CH}_{2}+\mathrm{CH}_{3} \rightarrow \mathrm{C}_{2} \mathrm{H}_{4}+\mathrm{H}$ & $5.0 \times 10^{-11}$ & $\begin{array}{l}\text { Pilling and Robertson, } \\
1975\end{array}$ \\
\hline $\begin{array}{l}(110){ }^{3} \mathrm{CH}_{2}+\mathrm{C}_{2} \mathrm{H}_{2} \stackrel{\mathrm{M}}{\rightarrow} \mathrm{C}_{3} \mathrm{H}_{4} \\
\text { (111) } \mathrm{C}_{2} \mathrm{H}_{2}+\mathrm{OH} \rightarrow \mathrm{CO}+\mathrm{CH}_{3}\end{array}$ & $\begin{array}{l}7.5 \times 10^{-12} \\
2.0 \times 10^{-12} \exp (-250 / T)\end{array}$ & $\begin{array}{l}\text { Laufer and Bass, } 1974 \\
\text { Hampson and Garvin, } \\
1977\end{array}$ \\
\hline
\end{tabular}


Table I (continued)

\begin{tabular}{|c|c|c|}
\hline Reaction & Rate constant $\left(\mathrm{cm}^{3} \mathrm{~s}^{-1}\right)$ & Reference \\
\hline 12) $\mathrm{C}_{2} \mathrm{H}_{2}+\mathrm{H}+\mathrm{M} \rightarrow \mathrm{C}_{2} \mathrm{H}_{3}+\mathrm{M}$ & $\begin{array}{c}\operatorname{Min}\left[9.2 \times 10^{-12} \exp (-1205 / T)\right. \\
\left.10^{-30} \exp (-770 / T)[\mathrm{M}]\right]\end{array}$ & Payne and Stief, 1976 \\
\hline (113) $\mathrm{C}_{2} \mathrm{H}_{3}+\mathrm{H} \rightarrow \mathrm{C}_{2} \mathrm{H}_{2}+\mathrm{H}_{2}$ & $7.0 \times 10^{-12}$ & $\begin{array}{l}\text { Benson and Haugen, } \\
1967\end{array}$ \\
\hline (114) $\mathrm{C}_{2} \mathrm{H}_{3}+\mathrm{H}_{2} \rightarrow \mathrm{C}_{2} \mathrm{H}_{4}+\mathrm{H}$ & $3.0 \times 10^{-13} \exp (-5570 / T)$ & Yung and Strobel, 1980 \\
\hline (115) $\mathrm{C}_{2} \mathrm{H}_{3}+\mathrm{CH}_{4} \rightarrow \mathrm{C}_{2} \mathrm{H}_{4}+\mathrm{CH}_{3}$ & $3.0 \times 10^{-13} \exp (-5370 / T)$ & Estimated ${ }^{\mathrm{i}}$ \\
\hline (116) $\begin{aligned} & \mathrm{C}_{2} \mathrm{H}_{3}+\mathrm{C}_{2} \mathrm{H}_{6} \rightarrow \mathrm{C}_{2} \mathrm{H}_{4} \\
& +\mathrm{C}_{2} \mathrm{H}_{5}\end{aligned}$ & $3.0 \times 10^{-13} \exp (-5170 / T)$ & Estimated $^{\mathrm{i}}$ \\
\hline (117) $\mathrm{C}_{2} \mathrm{H}_{4}+\mathrm{OH} \rightarrow \mathrm{H}_{2} \mathrm{CO}+\mathrm{CH}_{3}$ & $2.2 \times 10^{-12} \exp (385 / T)$ & $\begin{array}{l}\text { Hampson and Garvin, } \\
1977\end{array}$ \\
\hline (118) $\mathrm{C}_{2} \mathrm{H}_{4}+\mathrm{O} \rightarrow \mathrm{HCO}+\mathrm{CH}_{3}$ & $5.5 \times 10^{-12} \exp (-565 / T)$ & $\begin{array}{l}\text { Hampson and Garvin, } \\
1977\end{array}$ \\
\hline (119) $\mathrm{C}_{2} \mathrm{H}_{4}+\mathrm{H}+\mathrm{M} \rightarrow \mathrm{C}_{2} \mathrm{H}_{5}+\mathrm{M}$ & $\begin{array}{c}\operatorname{Min}\left[3.7 \times 10^{-11} \exp (-1040 / T)\right. \\
\left.3.0 \times 10^{-30}[\mathrm{M}]\right]\end{array}$ & Lee \\
\hline $\begin{array}{c}(120) \mathrm{C}_{3} \mathrm{H}_{6}+\mathrm{OH} \rightarrow \mathrm{CH}_{3} \mathrm{CHO} \\
+\mathrm{CH}_{3}\end{array}$ & $4.1 \times 10^{-12} \exp (540 / T)$ & $\begin{array}{l}\text { Hampson and Garvin, } \\
1977\end{array}$ \\
\hline (121) $\mathrm{C}_{3} \mathrm{H}_{6}+\mathrm{O} \rightarrow 2 \mathrm{CH}_{3}+\mathrm{CO}$ & $4.1 \times 10^{-12} \exp (-38 / T)$ & $\begin{array}{l}\text { Hampson and Garvin, } \\
1977^{\mathrm{h}}\end{array}$ \\
\hline (122) $\mathrm{C}_{3} \mathrm{H}_{6}+\mathrm{H}+\mathrm{M} \rightarrow \mathrm{C}_{3} \mathrm{H}_{7}+\mathrm{M}$ & $(=\mathrm{R} 11$ & Estin \\
\hline $\begin{array}{l}(123) \mathrm{C}_{4} \mathrm{H}_{8}+\mathrm{OH} \rightarrow \mathrm{C}_{2} \mathrm{H}_{5} \mathrm{CHO} \\
+\mathrm{CH}_{3}\end{array}$ & $i=F$ & 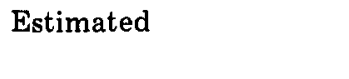 \\
\hline $\begin{array}{c}(124) \mathrm{C}_{4} \mathrm{H}_{8}+\mathrm{O} \rightarrow \mathrm{CH}_{3}+\mathrm{C}_{2} \mathrm{H}_{5} \\
+\mathrm{CO}\end{array}$ & $(=\mathrm{R} 121)$ & Estimated \\
\hline (125) $\mathrm{C}_{4} \mathrm{H}_{8}+\mathrm{H}+\mathrm{M} \rightarrow \mathrm{C}_{4} \mathrm{H}_{9}+\mathrm{M}$ & $(=\mathrm{R} 119)$ & Estin \\
\hline (126) $\mathrm{C}_{2} \mathrm{H}+\mathrm{O}_{2} \rightarrow \mathrm{CO}+\mathrm{HCO}$ & $1.0 \times 10^{-10}$ & stimated $^{\mathrm{h}}$ \\
\hline (127) $\mathrm{C}_{2} \mathrm{H}+\mathrm{H}_{2} \rightarrow \mathrm{C}_{2} \mathrm{H}_{2}+\mathrm{H}$ & $3.0 \times 10^{-11} \exp (-1600 / T)$ & Estimated ${ }^{\mathrm{j}}$ \\
\hline (128) $\mathrm{C}_{2} \mathrm{H}+\mathrm{CH}_{4} \rightarrow \mathrm{C}_{2} \mathrm{H}_{2}+\mathrm{CH}_{3}$ & $3.0 \times 10^{-11} \exp (-1400 / T)$ & Estimated $^{\mathrm{j}}$ \\
\hline (129) $\mathrm{C}_{2} \mathrm{H}+\mathrm{C}_{2} \overrightarrow{\mathrm{H}}_{6} \rightarrow \mathrm{C}_{2} \mathrm{H}_{2}+\mathrm{C}_{2} \mathrm{H}_{s}$ & $3.0 \times 10^{-11} \exp (-1200 / T)$ & Estimated $^{\mathrm{j}}$ \\
\hline$(130) \mathrm{C}_{2} \mathrm{H}+\mathrm{H}+\mathrm{M} \rightarrow \mathrm{C}_{2} \mathrm{H}_{2}+\mathrm{M}$ & $(=\mathrm{R} 50)$ & Estimated \\
\hline (131) $\mathrm{C}_{2} \mathrm{H}+\mathrm{C}_{2} \mathrm{H}_{2} \rightarrow \mathrm{C}_{4} \mathrm{H}_{2}+\mathrm{H}$ & $3.1 \times 10^{-11}$ & Laufer and Bass, 1979 \\
\hline (132) $\mathrm{C}_{3} \mathrm{H}_{4}$ & $1.0 \times 10$ & Assumed ${ }^{k}$ \\
\hline (133) $\mathrm{C}_{4} \mathrm{H}_{2} \rightarrow$ dust & $1.0 \times 10^{-10}$ & Assumed $^{\mathrm{k}}$ \\
\hline (134) $\mathrm{CH}_{3}+\mathrm{h} \nu \rightarrow{ }^{3} \mathrm{CH}_{2}+\mathrm{H}$ & $5.0 \times 10^{-5}$ & Estimated $^{1}$ \\
\hline
\end{tabular}

${ }^{\mathrm{a}} A=1.82 \times 10^{-20}$.

bAssumed equal to R52.

c Assumed equal to R49.

d By comparison with R54 and R71.

e Assumed equal to R62.

${ }^{f}$ Branching ratios assumed to be wavelength independent.

${ }^{g}$ Assumed equal to half the rate measured by Becker et al. (1971) for quenching by $\mathrm{H}_{2}$.

hProducts uncertain.

${ }^{i}$ By comparison with R114, with correction for the expected difference in activation energies.

j. Estimated by Allen et al. (1980) based on results of Laufer and Bass (1979).

k See text.

${ }^{1}$ By comparison with rate estimated by Allen et al. (1980) for Titan.

${ }^{m}$ Barassin and Combourie (1974) give $5.8 \times 10^{-11} \exp (-4450 / T)$. 
A third possibility is recombination with another methyl radical to form ethane

$$
\mathrm{CH}_{3}+\mathrm{CH}_{3}+\mathrm{M} \rightarrow \mathrm{C}_{2} \mathrm{H}_{6}+\mathrm{M} \text { (R53). }
$$

Reaction R53 occurs at the high-pressure limiting rate all the way up to 80 $\mathrm{km}$, so ethane can be formed efficiently throughout the model atmosphere.

Ethane, once formed, can undergo a sequence of reactions which are analogous to those of methane (R54-R61), the only essential difference being that the reaction of $\mathrm{H}$ with an ethyl radical

$$
\mathrm{C}_{2} \mathrm{H}_{5}+\mathrm{H} \rightarrow \mathrm{CH}_{3}+\mathrm{CH}_{3} \text { (57) }
$$

produces two methyls rather than reforming ethane. The recombination of ethyl radicals can then lead to the formation of propane and butane

$$
\mathrm{C}_{2} \mathrm{H}_{5}+\mathrm{CH}_{3}+\mathrm{M} \rightarrow \mathrm{C}_{3} \mathrm{H}_{8}+\mathrm{M}(\mathrm{R} 60) ; \mathrm{C}_{2} \mathrm{H}_{5}+\mathrm{C}_{2} \mathrm{H}_{5}+\mathrm{M} \rightarrow \mathrm{C}_{4} \mathrm{H}_{10}+\mathrm{M} \text { (R61). }
$$
According to Benson (1964) these reactions occur at essentially the same rate as the recombination of two methyl radicals (R53). The entire sequence of higher alkanes can, presumably, be generated in this fashion, so our exclusion of species heavier than butane might be expected to cause trouble in some circumstances. The effects of cutting off the alkane sequence at $n=$ 4 will be discussed in a later section. The polymerization process can also be reversed by the reaction of $\mathrm{H}$ with alkyl radicals, producing two smaller alkyls, as is the case for ethane.

The higher alkanes may be oxidized to form higher aldehydes in much the same way that methane is oxidized to formaldehyde. Since the $\mathrm{C}-\mathrm{O}$ bonds formed in this process cannot be broken again within the atmosphere, each aldehyde molecule formed corresponds to a net loss of one methane molecule. The loss of methane via such oxidation processes must be balanced by a ground-level source of methane in order to maintain a constant $\mathrm{CH}_{4}$ mixing ratio in the atmosphere.

At altitudes above about $40 \mathrm{~km}$ methane may also be destroyed by direct photolysis

$$
\mathrm{CH}_{4}+\mathrm{h} \nu \rightarrow{ }^{1} \mathrm{CH}_{2}+\mathrm{H}_{2} \text { (R79). }
$$

Since the photolysis of methane (and the higher alkanes) requires wavelengths shorter than $1600 \AA$, this process is responsible for only a small fraction of total methane destruction. The by-products of methane photolysis may react to form unsaturated hydrocarbons such as acetylene and ethylene via

$$
{ }^{3} \mathrm{CH}_{2}+{ }^{3} \mathrm{CH}_{2} \rightarrow \mathrm{C}_{2} \mathrm{H}_{2}+2 \mathrm{H}(\mathrm{R} 108) ;{ }^{3} \mathrm{CH}_{2}+\mathrm{CH}_{3} \rightarrow \mathrm{C2H}_{4}+\mathrm{H} \text { (R109). }
$$

Acetylene, in particular, is potentially important because it can catalytically destroy atomic hydrogen by

$$
\mathrm{C}_{2} \mathrm{H}_{2}+\mathrm{H}+\mathrm{M} \rightarrow \mathrm{C}_{2} \mathrm{H}_{3}+\mathrm{M}(\mathrm{R} 112) ; \mathrm{C}_{2} \mathrm{H}_{3}+\mathrm{H} \rightarrow \mathrm{C}_{2} \mathrm{H}_{2}+\mathrm{H}_{2} \text { (R113). }
$$

In these models, however, the catalytic cycle involving $\mathrm{CO}$ is much more important

$$
\mathrm{CO}+\mathrm{H}+\mathrm{M} \rightarrow \mathrm{HCO}+\mathrm{M}(\mathrm{R} 32) ; \mathrm{HCO}+\mathrm{H} \rightarrow \mathrm{CO}+\mathrm{H}_{2} \text { (R33). }
$$

Acetylene can also react with different radical species to produce polyunsaturated hydrocarbon compounds. We have identified two such pathways in the model

$$
{ }^{3} \mathrm{CH}_{2}+\mathrm{C}_{2} \mathrm{H}_{2}+\mathrm{M} \rightarrow \mathrm{C}_{3} \mathrm{H}_{4}+\mathrm{M}(\mathrm{R} 110) \text { and } \mathrm{C}_{2} \mathrm{H}+\mathrm{C}_{2} \mathrm{H}_{2} \rightarrow \mathrm{C}_{4} \mathrm{H}_{2}+\mathrm{H}(\mathrm{R} 131) \text {. }
$$


Reaction R110 forms methylacetylene and allene in roughly a $1: 2$ ratio (Laufer and Bass, 1974) and is the largest source of polyunsaturated compounds in our model. Reaction 131 yields butadiene, which has been suggested as a precursor to the formation of Danielson dust on Titan (Allen et al., 1980). In this model we assume, somewhat arbitrarily, that both $\mathrm{C}_{3} \mathrm{H}_{4}$ and $\mathrm{C}_{4} \mathrm{H}_{2}$ are eventually removed from the atmosphere by conversion to some solid polymer. This assumption yields an estimate for the maximum possible loss of methane that can result from these two processes.

\section{RESULTS}

One of the difficulties in conducting a study of this kind is that the atmospheric mixing ratios of hydrogen and carbon dioxide are not known. Indeed, both $\mathrm{H}_{2}$ and $\mathrm{CO}_{2}$ levels are likely to have varied during $\sim 2 \mathrm{Ga}$ prior to the development of an oxygenic atmosphere. Reasonable values for the $\mathrm{H}_{2}$ mixing ratio range from $10^{-5}$ to $10^{-3}$ (Kasting and Walker, 1981), while the $\mathrm{CO}_{2}$ mixing ratio was probably between one and several hundred PAL (Owen et al., 1979; Walker et al., 1981). The calculations described here assume a range of possible mixing ratios for each of these gases.

As an initial experiment, the ground-level $\mathrm{H}_{2}$ and $\mathrm{CO}_{2}$ mixing ratios were fixed at $10^{-4}$ and $4.17 \times 10^{-4}$, respectively. (This is the equivalent of $1 \mathrm{PAL}$ of $\mathrm{CO}_{2}$ since the total atmospheric pressure is only 0.8 bars.) Calculations were performed for $\mathrm{CH}_{4}$ mixing ratios ranging from $10^{-6}$ to $5 \times 10^{-4}$. Plotted in Fig. 1 are the calculated atmospheric residence time for methane and the ground-level methane source required to maintain the atmosphere in steady

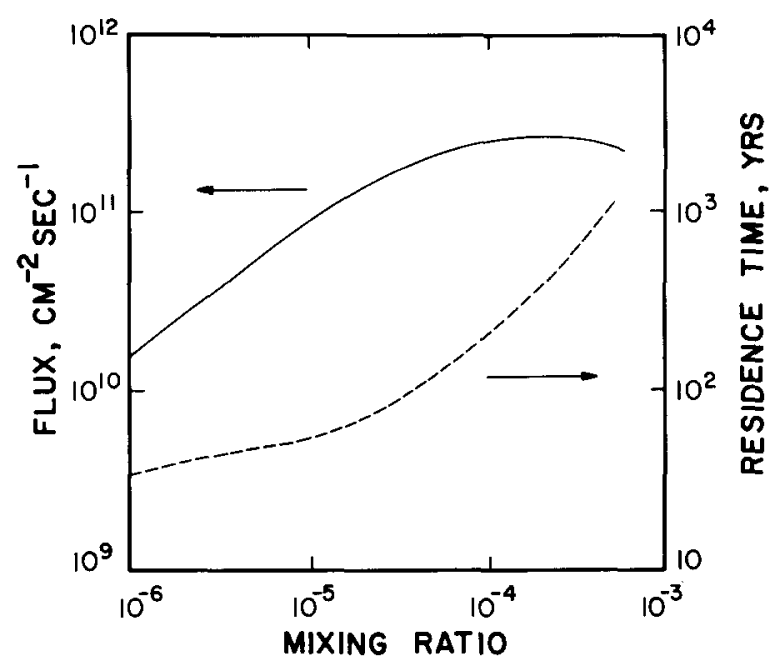

Fig. 1. Methane flux (solid curve) and atmospheric residence time (dashed curve) as a function of ground-level $\mathrm{CH}_{4}$ mixing ratio. The assumed $\mathrm{H}_{2}$ and $\mathrm{CO}_{2}$ mixing ratios are $10^{-4}$ and 1 PAL, respectively. 
state. Figure 1 illustrates several important points. First, the $\mathrm{CH}_{4}$ residence times range from a few tens to a few thousands of years. Similar values were encountered over the entire range of different background atmospheres examined. Since a few thousand years is insignificant on a geological time scale, it is clear that only steady-state scenarios with a constant source for methane are of interest here. Second, the methane source required to maintain a $\mathrm{CH}_{4}$ mixing ratio of several ppm is in the order of $10^{11} \mathrm{CH}_{4}$ molecules $\mathrm{cm}^{-2} \mathrm{~s}^{-1}$. This figure is roughly equivalent to estimates for the present-day source of atmospheric methane (Koyama, 1963; Baker-Blocker et al., 1977; Ehhalt and Schmidt, 1978; Kasting and Donahue, 1980). We shall argue later that a source of this magnitude could have existed throughout much of the Archean. A third point - one that is considerably less certain - is the suggestion that the required methane flux reaches a maximum as the methane mixing ratio is increased above $\sim 3 \times 10^{-4}$, actually beginning to decrease for higher mixing ratios. The explanation is that interconversions among the hydrocarbon species are consuming a larger percentage of the oxidizing radicals. This phenomenon might disappear, however, in a model which included alkanes higher than $\tilde{n}=4$.

Figure 2 shows altitude profiles of $\mathrm{CO}$ and the dominant hydrocarbon species for a methane mixing ratio $f\left(\mathrm{CH}_{4}\right)=10^{-5}$. The higher alkanes are all poorly represented, while $\mathrm{C}_{2} \mathrm{H}_{2}$ and $\mathrm{C}_{2} \mathrm{H}_{4}$ are confined almost exclusively to the upper atmosphere. A few features concerning the overall structure of the atmosphere deserve comment. First, the lower atmosphere is more highly reduced than the upper atmosphere. Second, the main photolysis paths begin with the dissociation of $\mathrm{H}_{2} \mathrm{O}$ below $20 \mathrm{~km}$, and of $\mathrm{CO}_{2}$ above $10 \mathrm{~km}$. Third, $\mathrm{CO}$ is much less abundant in the troposphere than in the stratosphere. Tropospherically produced OH (R25) is the main sink of this gas, via

$\mathrm{CO}+\mathrm{OH} \rightarrow \mathrm{CO}_{2}+\mathrm{H}(\mathrm{R} 30)$.

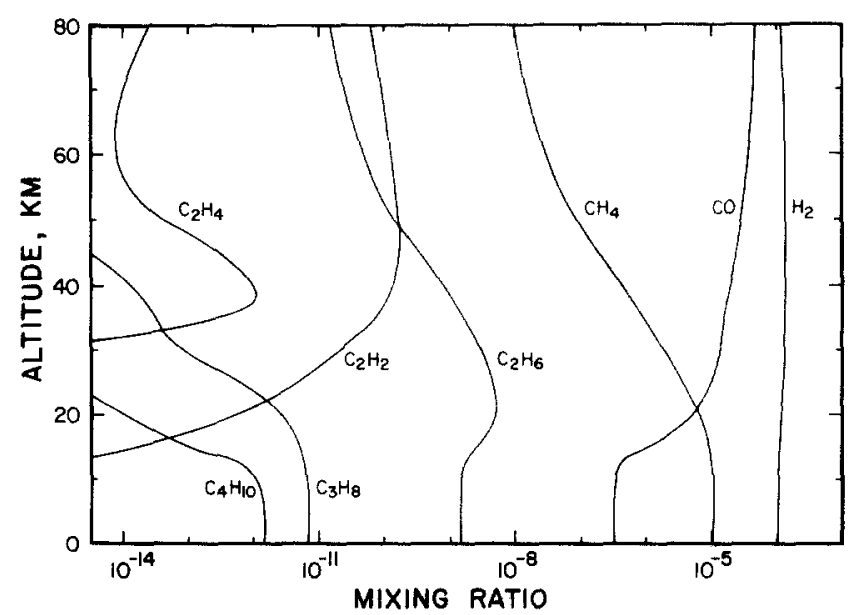

Fig. 2. Mixing ratio profiles of major reduced species at $f\left(\mathrm{CH}_{4}\right)=10^{-5}, f\left(\mathrm{H}_{2}\right)=10^{-4}$, and $f\left(\mathrm{CO}_{2}\right)=1$ PAL. 
Figure 3 shows alkane mixing ratios for $f\left(\mathrm{CH}_{4}\right)=10^{-4}$. The alkanes have all become quite prominent and acetylene has begun to appear in the troposphere. The CO mixing ratio has also increased substantially in the troposphere, as the increasingly reduced conditions have greatly lowered the $O$ and $\mathrm{OH}$ densities. Increasing $\mathrm{CO}$ acts to decrease $\mathrm{H}$, by means of the catalytic cycle R32-R33, and thus, tends to increase the efficiency of alkane polymerization. The prediction that the tropospheric $\mathrm{C}_{4} \mathrm{H}_{10}$ density exceeds that of $\mathrm{C}_{3} \mathrm{H}_{8}$ is an artifact of our truncated alkane sequence. In the lowest $20 \mathrm{~km}$ of the atmosphere shown in Fig. 3 the densities of the alkyl radicals tend to increase with increasing molecular weight. This would result, in a more complete model, in the formation of significant amounts of still higher alkanes. Our results are, therefore, not very meaningful for $\mathrm{CH}_{4}$ mixing ratios above $10^{-4}$.

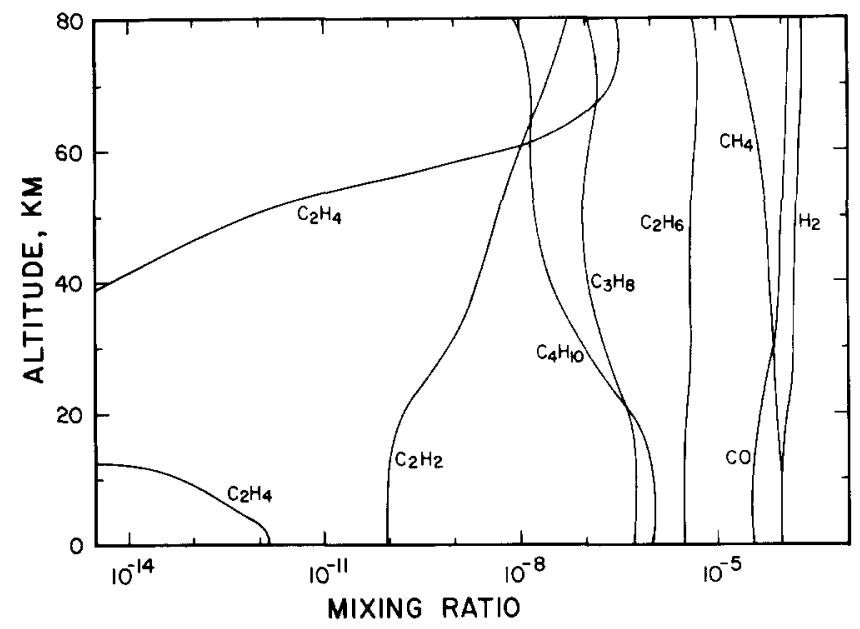

Fig. 3. The same as Fig. 2, except $f\left(\mathrm{CH}_{4}\right)=10^{-4}$.

The effects on the $\mathrm{CO}$ and $\mathrm{C}_{2} \mathrm{H}_{6}$ mixing ratios of varying methane mixing ratio at $1 \mathrm{PAL} \mathrm{CO}_{2}$ and $f\left(\mathrm{H}_{2}\right)=10^{-4}$ are summarized in Fig. 4. All mixing ratios here refer to ground-level.

The trend towards alkane polymerization at high methane levels is accompanied by increased production of polyunsaturated hydrocarbons. Figure 5 shows column-integrated production rates for $\mathrm{C}_{3} \mathrm{H}_{4}$ and $\mathrm{C}_{4} \mathrm{H}_{2}$ as a function of methane mixing ratio. The rate of polymerization via these two channels becomes substantial at $\mathrm{CH}_{4}$ mixing ratios near $10^{-4}$, although it never exceeds a few percent of the methane oxidation rate (Fig. 1). We have not attempted to determine the subsequent fate of $\mathrm{C}_{3} \mathrm{H}_{4}$ and $\mathrm{C}_{4} \mathrm{H}_{2}$ in this model. It is conceivable, however, that they may have led to the formation of stratospheric dust in much the same fashion as has been suggested to occur in the atmosphere of Titan (Allen et al., 1980). 


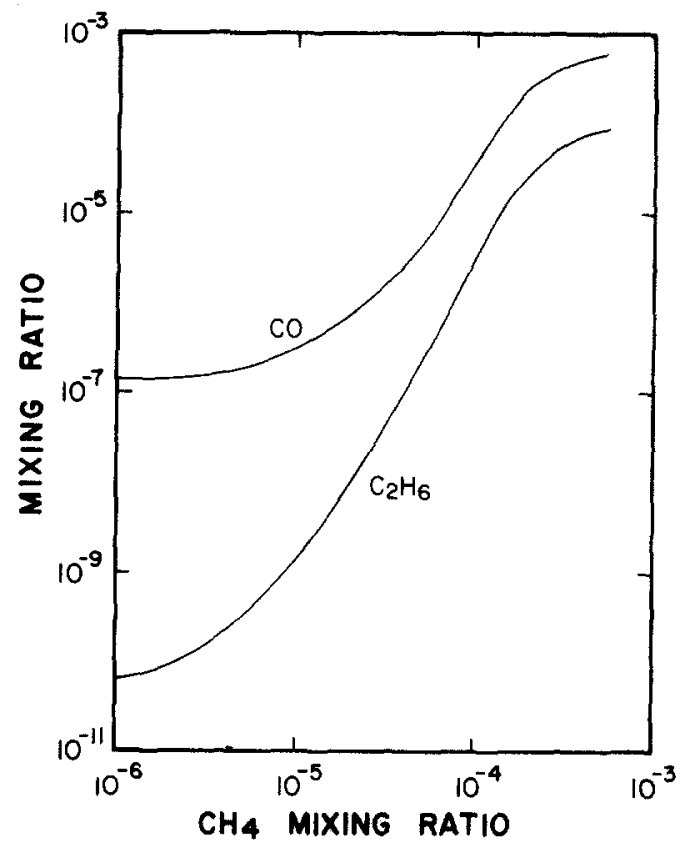

Fig. 4. Variation of $\mathrm{CO}$ and $\mathrm{C}_{2} \mathrm{H}_{6}$ with $\mathrm{CH}_{4}$ mixing ratio for $f\left(\mathrm{CO}_{2}\right)=1$ PAL and $f\left(\mathrm{H}_{2}\right)=$ $10^{-4}$.

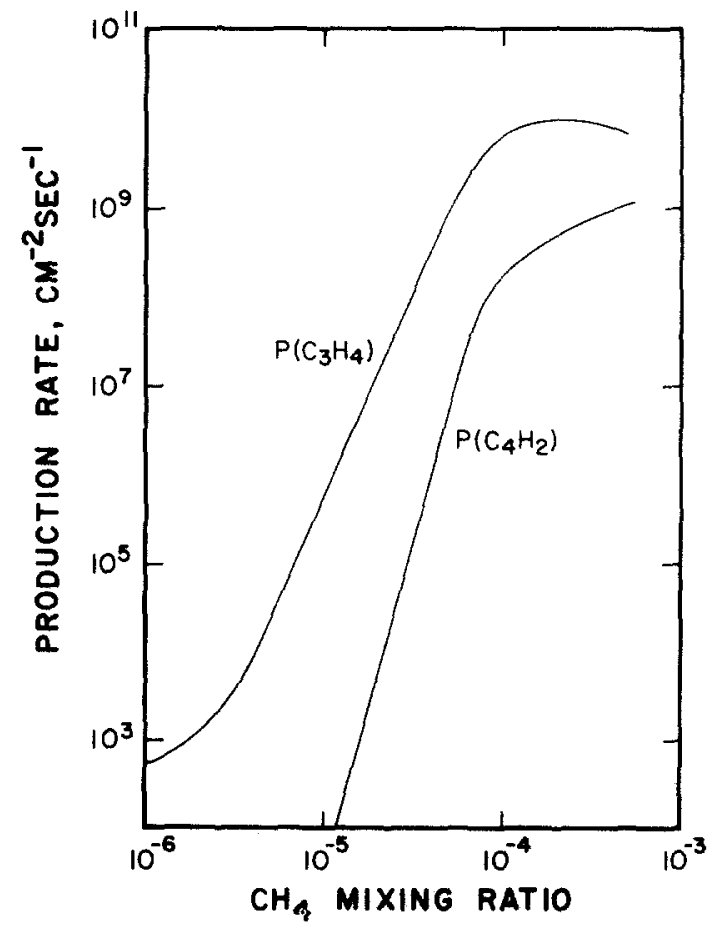

Fig. 5. Column-integrated production rates of $\mathrm{C}_{3} \mathrm{H}_{4}$ and $\mathrm{C}_{4} \mathrm{H}_{2}$ as functions of ground-level $\mathrm{CH}_{4}$ mixing ratio. The assumed $\mathrm{H}_{2}$ and $\mathrm{CO}_{2}$ mixing ratios are $10^{-4}$ and $1 \mathrm{PAL}$, respectively. 
The results presented so far correspond to an amount of $\mathrm{CO}_{2}$ in the early atmosphere equal to today's value. We suggested earlier, though, that primitive $\mathrm{CO}_{2}$ levels of 10-100 PAL are entirely possible, perhaps even likely. What effect would enhanced carbon dioxide levels have had upon the photochemistry of atmospheric methane?

Figure 6 shows calculated hydrocarbon mixing ratios for $f\left(\mathrm{CH}_{4}\right)=10^{-5}$, $f\left(\mathrm{H}_{2}\right)=10^{-4}$ and a $\mathrm{CO}_{2}$ mixing ratio of $10 \mathrm{PAL}$. Comparison with Fig. 2 shows that hydrocarbon concentrations have increased dramatically: propane and butane have been enhanced by $\sim 5$ orders of magnitude, and ethane has become comparable to methane. The other hydrocarbons are similarly affected and, notably, so too is CO.

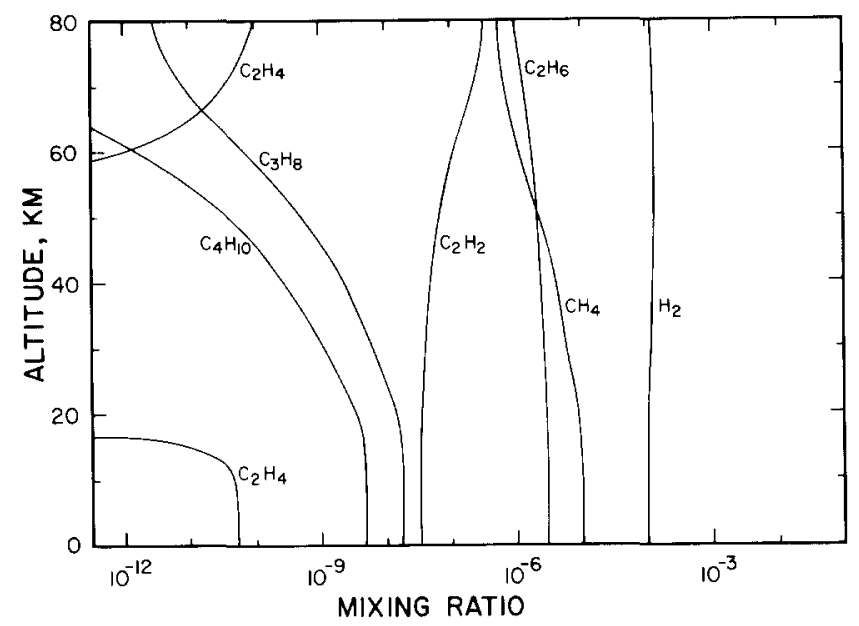

Fig. 6. Mixing ratio profiles of major reduced species at $f\left(\mathrm{CH}_{4}\right)=10^{-5}, f\left(\mathrm{H}_{2}\right)=10^{-4}$, and $f\left(\mathrm{CO}_{2}\right)=10$ PAL.

Figure 7 shows calculated hydrocarbon and $\mathrm{CO}$ mixing ratios for $f\left(\mathrm{CH}_{4}\right)=$ $10^{-5}$ and $f\left(\mathrm{H}_{2}\right)=10^{-4}$ at $100 \mathrm{PAL}$ of $\mathrm{CO}_{2}$. The hydrocarbons are all somewhat less abundant than at $10 \mathrm{PAL}$, but $\mathrm{CO}$ now constitutes $\sim 0.1 \%$ of the atmosphere.

Figure 8 summarizes these results by showing the effect of varying $\mathrm{CO}_{2}$ on $\mathrm{CO}, \mathrm{C}_{2} \mathrm{H}_{6}$ and the required methane flux for $f\left(\mathrm{H}_{2}\right)=10^{-4}$ and $f\left(\mathrm{CH}_{4}\right)=10^{-5}$. Although the details are complex, the underlying cause of this behavior is that the increased $\mathrm{CO}_{2}$ absorbs a larger fraction of the incident photolyzing flux, and does so higher in the atmosphere. Thus, there is more primary production of $\mathrm{CO}$ and $\mathrm{O}$ by R29, and less of $\mathrm{H}$ and $\mathrm{OH}$ by R27, and photolysis in the shielded troposphere becomes less important.

As $\mathrm{CO}_{2}$ is increased from 1 to $10 \mathrm{PAL}$, the initial effect of reducing the rate of tropospheric water photolysis is to greatly weaken the primary atmospheric sink for CO (R30) and so CO increases. The combined effects of decreased photolytic production and increased catalytic removal by the CO cycle 


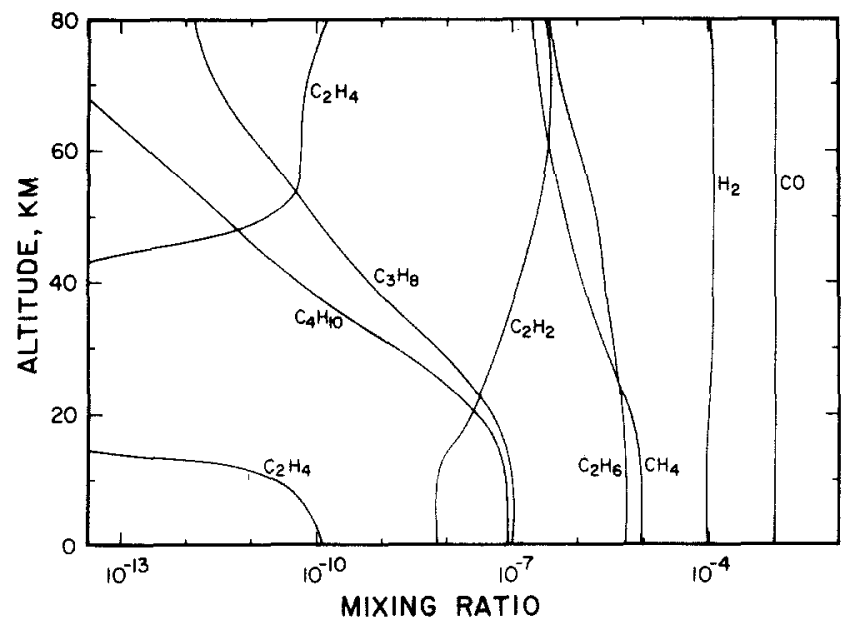

Fig. 7. The same as Fig. 6, except $f\left(\mathrm{CO}_{2}\right)=100 \mathrm{PAL}$.

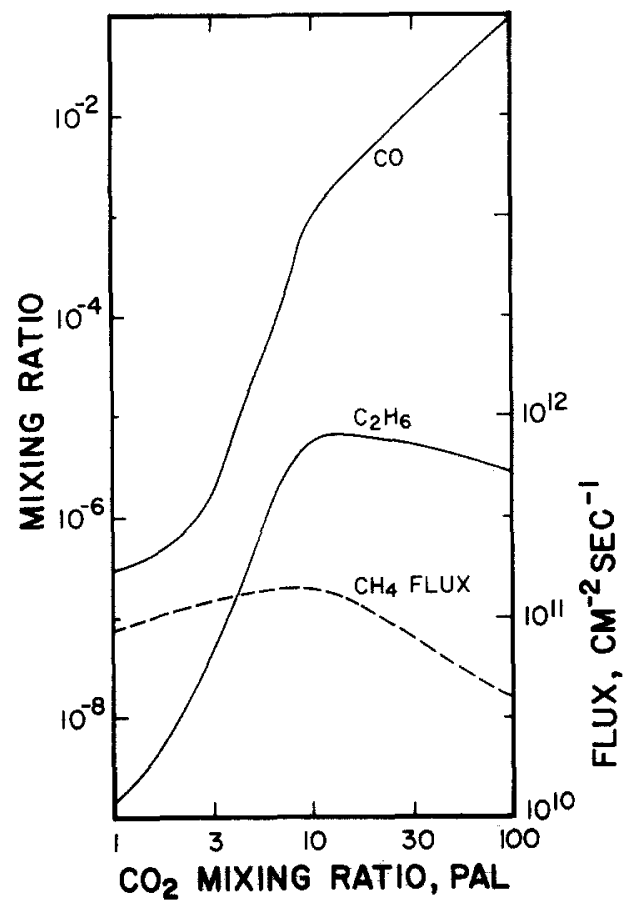

Fig. 8. Dependence on $f\left(\mathrm{CO}_{2}\right)$ of $f(\mathrm{CO}), f\left(\mathrm{C}_{2} \mathrm{H}_{6}\right)$, and the methane flux required to maintain a steady state for $f\left(\mathrm{H}_{2}\right)=10^{-4}$ and $f\left(\mathrm{CH}_{4}\right)=10^{-5}$.

(R32-33) greatly decrease tropospheric $\mathrm{H}$ densities. Thus, the reaction of $\mathrm{CH}_{3}$ with itself (R53) becomes faster than the reaction of $\mathrm{CH}_{3}$ with $\mathrm{H}$ (R50), so the rate of ethane formation is dramatically increased. A quirk in the alkane chemistry further favors the production of polymers. The reported re- 
action rates of $\mathrm{CH}_{4}$ with $\mathrm{O}$ and $\mathrm{OH}$ ( $\mathrm{R} 48$ and $\mathrm{R} 47$ ) are approximately equally fast in the troposphere (see discussion of limitations below), but for the higher alkanes, the analogous reaction with $O$ is roughly 100 times slower than the analogous reaction with $\mathrm{OH}$. Hence, as decreasing rates of water photolysis and increasing mixing ratios of $\mathrm{CO}$ combine to reduce tropospheric $\mathrm{OH}$ densities, the switch to $\mathrm{O}$ as the dominant oxidizing radical increases the lifetimes of the higher alkanes while not seriously slowing the methyl formation rate.

At $\mathrm{CO}_{2}$ mixing ratios above $10 \mathrm{PAL}$, water photolysis plays an almost negligible role. The basic chemistry of this atmosphere is reduced to the photolysis of $\mathrm{CO}_{2}$ and its recombination. In the absence of an efficient means of removing $\mathrm{CO}$, the relatively slow direct 3 -body recombination (which is inhibited by a significant activation energy)

$\mathrm{CO}+\mathrm{O}+\mathrm{M} \rightarrow \mathrm{CO}_{2}+\mathrm{M}(\mathrm{R} 31)$

becomes important below about $20 \mathrm{~km}$. This reduces $\mathrm{O}$ densities in the lower atmosphere, slowing the alkane photochemistry, as indicated by the relatively low methane flux required at $100 \mathrm{PAL}$ of $\mathrm{CO}_{2}$.

A fairly complete set of model experiments was performed at $f\left(\mathrm{H}_{2}\right)=10^{4}$, including $f\left(\mathrm{CH}_{4}\right)=10^{-6}$ and $10^{-5}$ at $1-100 \mathrm{PAL} \mathrm{CO}_{2}$, and $f\left(\mathrm{CH}_{4}\right)=10^{-4}$ at $1-$ $10 \mathrm{PAL} \mathrm{CO}_{2}$. At $1 \mathrm{PAL}$, models with $f\left(\mathrm{CH}_{4}\right)=2.5 \times 10^{-4}$ and $5 \times 10^{-4}$ were run, but these are not able to treat the alkane chemistry properly. The dependence of the required source strength on $\mathrm{CH}_{4}$ and $\mathrm{CO}_{2}$ mixing ratios is illustrated explicitly in Fig. 9. The contours represent the base 10 logarithm of the methane source (molecules $\mathrm{cm}^{-2} \mathrm{~s}^{-1}$ ) needed to maintain the steady state. Figure 10 is a contour plot of the tropospheric ethane mixing ratio as a function of $\mathrm{CH}_{4}$ and $\mathrm{CO}_{2}$ mixing ratios. It illustrates regimes under which $\mathrm{CH}_{4}$

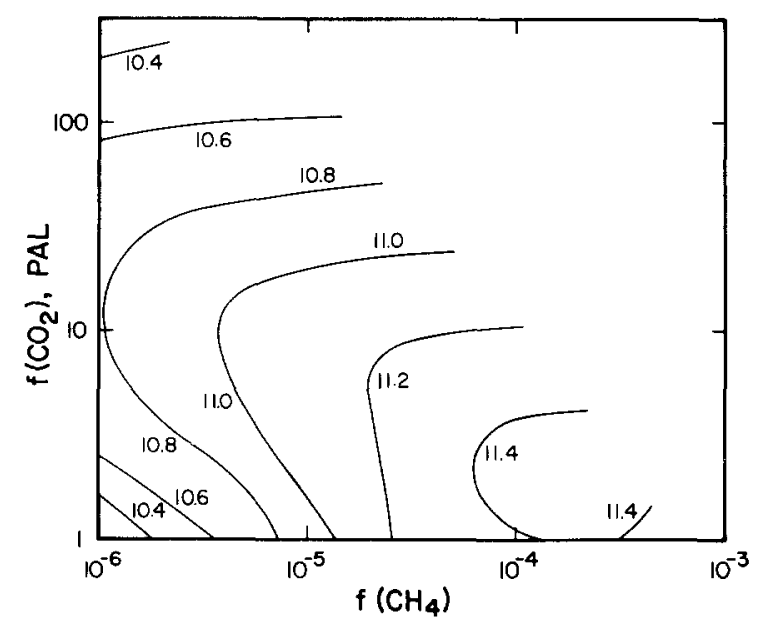

Fig. 9. Calculated ground-level methane fluxes needed to maintain the atmosphere in equilibrium for different $\mathrm{CH}_{4}$ and $\mathrm{CO}_{2}$ mixing ratios. Contours represent the base 10 logarithm of the required methane source in $\mathrm{CH}_{4}$ molecules $\mathrm{cm}^{-2} \mathrm{~s}^{-1}$. The mixing ratio of $\mathrm{H}_{2}=10^{-4}$. 


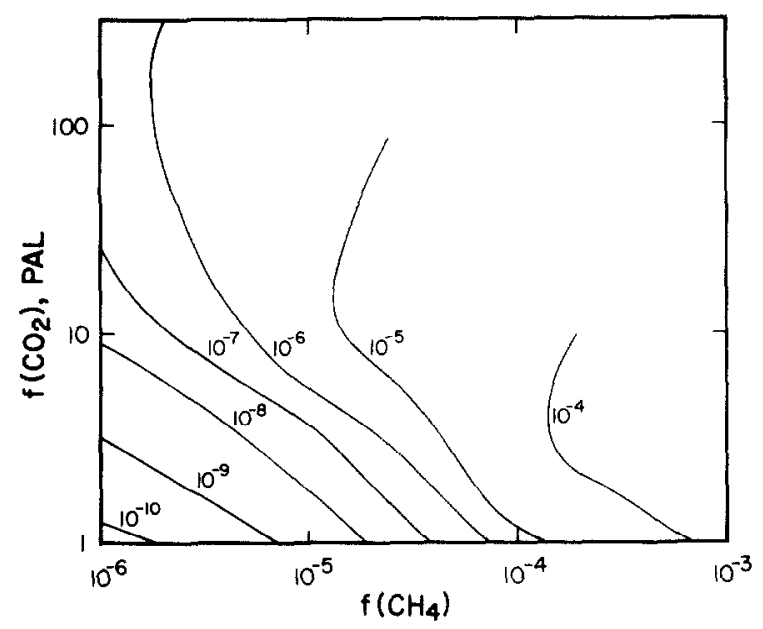

Fig. 10. Mixing ratio of $\mathrm{C}_{2} \mathrm{H}_{6}$ as a function of the mixing ratios of $\mathrm{CO}_{2}$ and $\mathrm{CH}_{4}$ for $f\left(\mathrm{H}_{2}\right)$ $=10^{-4}$.
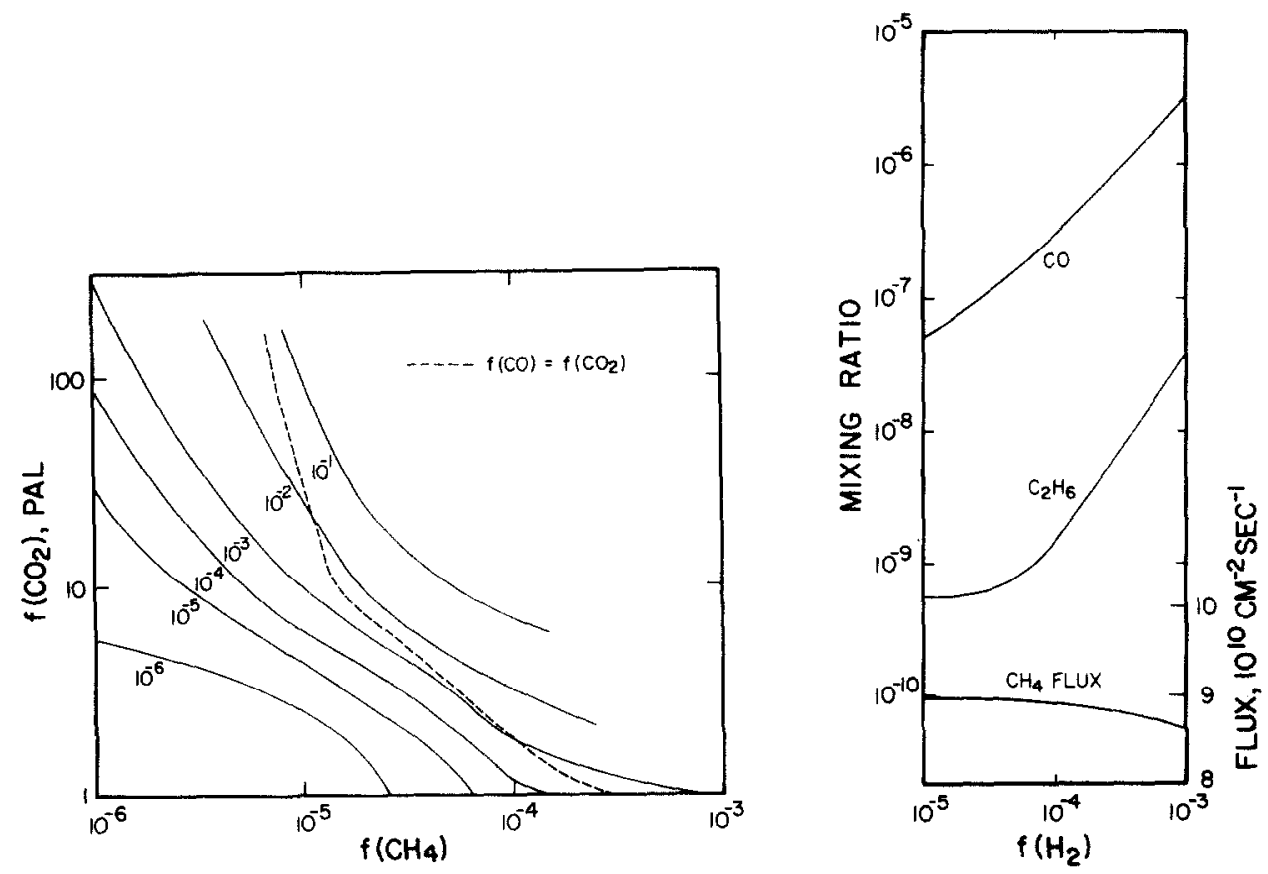

Fig. 11. Mixing ratio of $\mathrm{CO}$ as a function of the mixing ratios of $\mathrm{CO}_{2}$ and $\mathrm{CH}_{4}$ for $f\left(\mathrm{H}_{2}\right)$ $=10^{-4}$.

Fig. 12. Dependence on $f\left(\mathrm{H}_{2}\right)$ of $f(\mathrm{CO}), f\left(\mathrm{C}_{2} \mathrm{H}_{6}\right)$, and the methane flux required to maintain a steady state for $f\left(\mathrm{CH}_{4}\right)=10^{-5}$ and $f\left(\mathrm{CO}_{2}\right)=1 \mathrm{PAL}$. 
and $\mathrm{CO}_{2}$ polymerization may be expected to have been important at $f\left(\mathrm{H}_{2}\right)=$ $10^{-4}$. In order to be effective greenhouse gases, the higher alkanes and associated hydrocarbons, aldehydes, alcohols, etc. would presumably have had to assume mixing ratios $>\sim 10^{-6}$. Thus, a substantial greenhouse effect would not be expected below and to the left of the $f\left(\mathrm{C}_{2} \mathrm{H}_{6}\right)=10^{-6}$ contour.

The dependence of $f(\mathrm{CO})$ upon $\mathrm{CH}_{4}$ and $\mathrm{CO}_{2}$ at $f\left(\mathrm{H}_{2}\right)=10^{-4}$ is shown in Fig. 11. The upper right hand region of the plot corresponds to conditions in which $\mathrm{CO}$ replaces $\mathrm{CO}_{2}$ as the more stable carbon oxide. These atmospheres are quite reducing in character. However, at high $\mathrm{CO}$ mixing ratios it is possible that otherwise unimportant loss processes for $\mathrm{CO}$ (e.g., perhaps surface catalyzed oxidation of $\mathrm{CO}$ by $\mathrm{H}_{2} \mathrm{O}$ ) may act to prevent the dominance of $\mathrm{CO}$. In any event, the question of the stability of $\mathrm{CO}_{2}$ in the early terrestrial atmosphere requires more consideration.

Figure 12 shows the effect of varying the $\mathrm{H}_{2}$ mixing ratio from $10^{-5}$ to $10^{-3}$ for $f\left(\mathrm{CH}_{4}\right)=10^{-5}$ and $\mathrm{CO}_{2}=1 \mathrm{PAL}$. Both $\mathrm{CO}$ and $\mathrm{C}_{2} \mathrm{H}_{6}$ increase with increasing $\mathrm{H}_{2}$, but neither increases as rapidly or nonlinearly as when $\mathrm{CH}_{4}$ or $\mathrm{CO}_{2}$ are varied. The change in the required methane flux is very small indeed.

These effects are relatively easy to understand. Molecular hydrogen reacts with $\mathrm{OH}$

$$
\mathrm{H}_{2}+\mathrm{OH} \rightarrow \mathrm{H}+\mathrm{H}_{2} \mathrm{O}(\mathrm{R} 4) \text {, }
$$

so increased $\mathrm{H}_{2}$ decreases $\mathrm{OH}$ densities. Since $\mathrm{CO}$ is removed by $\mathrm{OH}$

$\mathrm{CO}+\mathrm{OH} \rightarrow \mathrm{CO}_{2}+\mathrm{H}(\mathrm{R} 30)$, $f(\mathrm{CO})$ should increase linearly with $f\left(\mathrm{H}_{2}\right)$, as is the case in Fig. 12 .

Ethane presents a more complex problem, since both its production and its loss are affected by changes in $\mathrm{H}_{2}$ concentrations. The dominant loss process for ethane at all $\mathrm{H}_{2}$ levels is the reaction with $\mathrm{OH}$

$$
\mathrm{C}_{2} \mathrm{H}_{6}+\mathrm{OH} \rightarrow \mathrm{C}_{2} \mathrm{H}_{5}+\mathrm{H}_{2} \mathrm{O}(\mathrm{R} 54) \text {, }
$$

so it can be expected that $\mathrm{C}_{2} \mathrm{H}_{6}$ concentrations should vary linearly with $f\left(\mathrm{H}_{2}\right)$, all other things being equal. However, the ethane production rate depends on $\mathrm{CH}_{3}$ concentrations and these, in turn, are affected by the densities of $\mathrm{H}$ and $\mathrm{OH}$. At low $\mathrm{H}_{2}$ levels, $\mathrm{CH}_{3}$ production stems largely from the reaction of $\mathrm{CH}_{4}$ with $\mathrm{OH}(\mathrm{R} 47)$. This tends to counteract the $\mathrm{OH}$ dependence of the loss rate, with the result that the ethane concentration is nearly independent of $f\left(\mathrm{H}_{2}\right)$. At high $\mathrm{H}_{2}$ levels, the $\mathrm{CO}$ catalytic cycle (R32-R33) tends to reduce $\mathrm{H}$ densities, which results in a slower rate of destruction of methyl radicals via the reaction of $\mathrm{CH}_{3}$ with $\mathrm{H}(\mathrm{R} 50)$. The $\mathrm{C}_{2} \mathrm{H}_{6}$ production rate is enhanced and so the ethane concentration increases faster than linearly with increasing $f\left(\mathrm{H}_{2}\right)$.

The required methane flux is almost independent of $\mathrm{H}_{2}$, because methane is oxidized almost exclusively in the stratosphere, by reactions with atomic oxygen ( $\mathrm{R} 48$ and R57). The reaction of $\mathrm{H}_{2}$ with $\mathrm{O}$ (R3) is very slow, and does not compete effectively for $\mathrm{O}$ atoms at the hydrogen mixing ratios considered here. 
Although we have not made a systematic evaluation of the effects of varying $\mathrm{H}_{2}$ at all $\mathrm{CH}_{4}$ and $\mathrm{CO}_{2}$ levels, we expect that at higher $\mathrm{CO}_{2}$ levels, variations in $\mathrm{H}_{2}$ would be even less important than they are at $1 \mathrm{PAL}$, since $\mathrm{OH}$ becomes a less important species that is effectively dominated by reaction with abundant $\mathrm{CO}$. For $\mathrm{H}_{2}$ to have a major effect would require enough $\mathrm{H}_{2}$ to force reaction with $\mathrm{O}$. This would require both $f\left(\mathrm{H}_{2}\right) \geqslant 10^{3} f\left(\mathrm{CH}_{4}\right)$ and $f\left(\mathrm{H}_{2}\right)$ $\gtrsim 30 f(\mathrm{CO})$ for the $\mathrm{C}-\mathrm{H}-\mathrm{O}$ atmospheres considered here.

\section{LIMITATIONS OF THE MODEL}

Obviously, considerable uncertainty arises in this calculation because of incomplete knowledge of hydrocarbon photochemistry. Our results are probably most secure at low methane and $\mathrm{CO}_{2}$ levels, where the primary photochemical pathway for methane is the relatively well understood process of oxidation to formaldehyde. At higher methane levels one of the chief problems is a poor understanding of the production and loss processes for acetylene. In this model we have minimized the importance of acetylene by including a number of speculative loss processes (R100, R110, R114-116 and R131) and only relatively well-known production processes. Consequently, $\mathrm{C}_{2} \mathrm{H}_{2}$ concentrations remain relatively low, even at high methane mixing ratios. The result is that the atomic hydrogen catalytic destruction cycle involving $\mathrm{C}_{2} \mathrm{H}_{2}$ (R112 and R113) is less effective than that involving CO (R32 and R33). Since lowered atomic hydrogen densities result in higher polymerization rates, our model is very sensitive to both of these cycles. An earlier version of this model, which did not include as many loss processes for acetylene, exhibited higher $\mathrm{C}_{2} \mathrm{H}_{2}$ concentrations and a more rapid onset of polymerization at high methane levels.

In general, uncertainty in an individual reaction rate does not pose a major problem - the exception is

$$
\mathrm{O}+\mathrm{CH}_{4} \rightarrow \mathrm{CH}_{3}+\mathrm{OH}(\mathrm{R} 48) \text {. }
$$

A much slower rate for $\mathrm{R} 48$ has been reported by Barassin and Combourie (1974). This rate strongly affects the details of the chemistry; in particular (for the case where $f\left(\mathrm{H}_{2}\right)=10^{-4}, f\left(\mathrm{CH}_{4}\right)=10^{-5}$, and $f\left(\mathrm{CO}_{2}\right)=1 \mathrm{PAL}$ ), the slower rate causes larger tropospheric $O$ densities, and hence delays the onset of hydrocarbon polymerization as a function of methane mixing ratio. The methane sustaining flux is also reduced by a factor of $\sim 2$; the flux calculations are much less sensitive to details of the chemistry, since the $\mathrm{CH}_{4}$ loss rate is largely a function of photon flux.

Another factor which would affect these results would be a change in the eddy diffusion profile. We have used the present-day profile from Hunten (1975), which assumes a very small value for the eddy diffusion coefficient in the lower stratosphere. In the absence of a temperature inversion due to ozone, the early atmosphere may have been more turbulent in this region. 
This would result in increased downward transport of $\mathrm{C}_{2} \mathrm{H}_{2}$ and $\mathrm{CO}$ and, consequently, in reduced atomic hydrogen concentrations in the troposphere. Thus, again, the degree of methane polymerization could have been greater than we have calculated here.

Another major problem with this model is the exclusion of alkanes of greater molecular weight than butane. If the rate of the three-body recombination remains unchanged for the higher alkyl radicals, the production of pentane, hexane and still higher alkanes cannot be ignored in atmospheres containing large amounts of $\mathrm{CH}_{4}$ or $\mathrm{CO}_{2}$. The situation is difficult to analyze because it is not clear where the polymerization process would stop. In a study of the primitive Martian atmosphere, Yung and Pinto (1978) predicted that alkanes heavier than heptane would condense to liquid form at temperatures expected to prevail on the Martian surface. The warmer surface temperature on the primitive Earth would prevent condensation until much higher molecular weights were attained. It may be that alkane mist would have condensed out of the colder regions of the stratosphere and then evaporated as it descended into the relatively warm troposphere. However, such speculation is probably premature at this time, due to uncertainty concerning the formation rates of the higher hydrocarbon species. Here we can only point out two expected effects of higher alkane formation on our results. First, by providing additional loss processes for $\mathrm{C}_{3} \mathrm{H}_{7}$ and $\mathrm{C}_{4} \mathrm{H}_{9}$, such reactions should tend to restore the normal ordering of alkane concentrations, whereby the densities decrease with increasing molecular weight. Second, oxidation and possibly condensation of higher alkanes would have constituted an additional drain on atmospheric methane, so the required methane source strength at high $\mathrm{CH}_{4}$ and $\mathrm{CO}_{2}$ levels may have been greater than we have calculated here.

The large $\mathrm{CO}$ concentrations predicted by our model at high $\mathrm{CH}_{4}$ and $\mathrm{CO}_{2}$ mixing ratios may be unrealistic. Possibly, $\mathrm{CO}$ could have been reduced to $\mathrm{CH}_{4}$ by catalytic processes occurring at the Earth's surface or in oceans. This reaction is favored thermodynamically, but requires a mechanism for breaking the $\mathrm{C}-\mathrm{O}$ bond. Direct photolysis of $\mathrm{CO}$ requires wavelengths shorter than $1100 \AA$ and could only occur high up in the atmosphere, but alternative gas phase pathways may exist. Bar-Nun and Chang (1983) recently reported methane and other hydrocarbons among the products formed by $1849 \AA \mathrm{ir}$ radiation of a gaseous mixture of $\mathrm{CO}$ and $\mathrm{H}_{2} \mathrm{O}$. The mechanism and efficiency of $\mathrm{CH}_{4}$ formation remains unclear. Additional study of this system would be of interest because of its implications for the composition of the primitive atmosphere.

The steady-state $\mathrm{CO} / \mathrm{CO}_{2}$ ratio is quite sensitive to tropospheric photolysis rates and the assumed water vapor profile. An earlier version of this model that did not include Rayleigh scattering predicted much smaller amounts of $\mathrm{CO}$ at high $\mathrm{CO}_{2}$ and $\mathrm{CH}_{4}$ mixing ratios, due to a more rapid rate of hydroxyl formation by photolysis of water vapor. The hydrocarbon chemistry considered here may well have produced aerosols similar to those observed on 
Titan, so the scattering optical depth of the atmosphere may have been much greater than assumed here.

Finally, due to our neglect of nitrogen chemistry, the present model overlooks the production of hydrogen cyanide - a compound of special interest to biochemists studying the origin of life. Hydrogen cyanide could have been formed at altitudes above $40 \mathrm{~km}$ by

$$
\mathrm{CH}_{4}+\mathrm{h} \nu \rightarrow \mathrm{CH}+\mathrm{H}_{2}+\mathrm{H}
$$

followed by

$$
\mathrm{CH}+\mathrm{N}_{2} \rightarrow \mathrm{HCN}+\mathrm{N}
$$

About $7 \%$ of methane photolysis reactions yield $\mathrm{CH}$ radicals (Gorden and Ausloos, 1967), which react with $\mathrm{N}_{2}$ at a rate of between $7.3 \times 10^{-14}$ (Braun et al., 1967) and $1 \times 10^{-12}$ (Bosnali and Perner, 1971). Hydrogen cyanide, like $\mathrm{CH}_{4}$, photolyzes only at very short wavelengths (Huebner and Carpenter, 1979), so most of the HCN produced at high altitudes could have survived long enough to be transported down into the lower atmosphere. Current studies of HCN in the atmosphere of Titan (Hanel et al., 1981) should shed more light on the photochemistry of this important molecule.

\section{TENTATIVE LIMITS ON METHANE IN THE ARCHEAN ATMOSPHERE}

We have shown that methane would have been an ephemeral constituent of an anaerobic primitive atmosphere of the kind considered here and could have remained in the atmosphere for geologically significant periods of time only if there was a continuous supply. Our calculations show that a source strength of about $10^{10}$ molecules $\mathrm{cm}^{-2} \mathrm{~s}^{-1}$ or larger would have been needed to sustain methane mixing ratios of $10^{-6}$, the lowest value likely to be of climatic significance.

The present-day flux of methane to the atmosphere has been estimated as about $10^{14}$ moles $\mathrm{y}^{-1}$ or $3.75 \times 10^{11}$ molecules $\mathrm{cm}^{-2} \mathrm{~s}^{-1}$ (Koyama, 1963; Baker-Blocker et al., 1977; Ehhalt and Schmidt, 1978; Kasting and Donahue, 1980). This flux is almost entirely of biogenic origin, being a product of methanogenic bacteria that derive energy mainly from the reaction

$\mathrm{CO}_{2}+4 \mathrm{H}_{2} \rightarrow \mathrm{CH}_{4}+2 \mathrm{H}_{2} \mathrm{O}$

(Wolfe, 1971; Deuser et al., 1973; Zeikus and Winfrey, 1976; Dacey and Klug, 1979). The hydrogen and carbon dioxide are products of microbial fermentation of organic matter in anaerobic environments (Gray and Gest, 1965)

$$
\mathrm{H}_{2} \mathrm{O}+\mathrm{CH}_{2} \mathrm{O} \rightarrow 2 \mathrm{H}_{2}+\mathrm{CO}_{2}
$$

Walker (1980a) has pointed out that much of the present day biogenic methane may be oxidized by microorganisms in overlying aerobic waters before reaching the atmosphere; with allowance for this loss, the total source of microbial methane today might be $10^{12} \mathrm{~cm}^{-2} \mathrm{~s}^{-1}$.

The total rate of photosynthetic fixation of carbon today is $2.6 \times 10^{13}$ atoms $\mathrm{cm}^{-2} \mathrm{~s}^{-1}$ using the tabulation of Holland (1978), so $\sim 4 \%$ of current 
productivity is converted into methane (Watson et al., 1978). On the anaerobic Earth, the fraction of organic carbon recycled as methane would presumably have been higher, but the productivity might well have been lower. The present day marine productivity of $1.1 \times 10^{13}$ atoms $\mathrm{cm}^{-2} \mathrm{~s}^{-1}$ might be a more plausible estimate of productivity during the Archean. A still more plausible estimate might be obtained by excluding open ocean productivity for reasons that have been discussed by Knoll (1979) and Walker (1978). The resulting estimate of a globally averaged carbon flux today of $2.7 \times 10^{12}$ atoms $\mathrm{cm}^{-2} \mathrm{~s}^{-1}$ is derived from the figures quoted by Koblentz-Mishke et al. (1970) for inshore and neritic waters. Such waters may, of course, have been rare on the Archean Earth.

Undoubted evidence of life extends back to $3.5 \mathrm{Ga}$ ago (Walter et al., 1980), and isotopic evidence for the activity of methanogenic bacteria as long ago as $2.7 \mathrm{Ga}$ has also been reported (Schoell and Wellmer, 1981; Hayes, 1983). Nor is the antiquity of the methanogens in doubt (Woese and Fox, 1977). Therefore, it seems possible that microorganisms on the Archean Earth might have generated a methane flux approaching $10^{12}$ molecules $\mathrm{cm}^{-2} \mathrm{~s}^{-1}$, depending on the fraction of fixed carbon converted into methane.

Possibly tighter constraints on the problem can be set by considering the oxidation-reduction balance of the atmosphere and ocean combined. The atmospheres we have described would have been losing hydrogen to space at a rate that can be estimated as

$F(\mathrm{H})=4 \times 10^{13}\left[2 f\left(\mathrm{H}_{2}\right)+2 f\left(\mathrm{H}_{2} \mathrm{O}\right)+4 f\left(\mathrm{CH}_{4}\right)\right]$ atoms $\mathrm{cm}^{-2} \mathrm{~s}^{-1}$

where $f\left(\mathrm{H}_{2} \mathrm{O}\right)=3.8 \times 10^{-6}$ is the mixing ratio of water vapor in the stratosphere, and $f\left(\mathrm{H}_{2}\right)$ and $f\left(\mathrm{CH}_{4}\right)$ are the mixing ratios of hydrogen and methane at the ground (Hunten, 1973; Hunten and Donahue, 1976; Walker, 1977; Kasting et al., 1979; Kasting and Walker, 1981). This loss of reducing power to space must have at least been balanced by a supply of reducing power to the atmosphere and ocean, or the world would have become aerobic (see discussion below). Evidence for a predominantly reducing atmosphere and ocean in the Archean has been summarized most recently by Walker et al. (1983).

The present-day flux of reduced volcanic and metamorphic gases to the atmosphere has been estimated by Kasting and Walker (1981) as equivalent to $8 \times 10^{8} \mathrm{H}$ atoms $\mathrm{cm}^{-2} \mathrm{~s}^{-1}$. The potential flux of divalent iron released by terrestrial weathering might be as large as $8 \times 10^{10} \mathrm{Fe}$ atoms $\mathrm{cm}^{-2} \mathrm{~s}^{-1}$ (Kasting and Walker, 1981), equivalent to $8 \times 10^{10} \mathrm{H}_{\text {atoms }} \mathrm{cm}^{-2} \mathrm{~s}^{-1}$ by way of the schematic reaction

$$
\mathrm{Fe}^{++}+3 \mathrm{H}_{2} \mathrm{O} \rightarrow \mathrm{Fe}(\mathrm{OH})_{3}+2 \mathrm{H}^{+}+\mathrm{H}
$$

We are aware of no estimate of the total flux of reduced species provided by submarine weathering today. This flux must be considerably less than the flux of oxygen into the deep sea, for otherwise the deep sea would be anoxic. Using numbers presented by Broecker (1974) we calculate an upper limit on 
the submarine weathering flux equivalent to $4 \times 10^{12} \mathrm{H}$ atoms $\mathrm{cm}^{-2} \mathrm{~s}^{-1}$. These estimates are all highly uncertain and their applicability to the distant past is even more uncertain, but we conclude that methane mixing ratios in the range $10^{-4}-10^{-6}$ are not obviously inconsistent with the maintenance of anaerobic conditions in the atmosphere and ocean. Such mixing ratios could have been sustained by a sufficiently abundant source of reduced iron in solution and a flourishing microbiota, including photoautotrophs, fermenting heterotrophs and methanogens. Oxidation-reduction balance could have been maintained by oxidation of the iron, either directly by the photoautotrophs (Walker, 1980a) or by reaction with photosynthetic oxygen

$4 \mathrm{Fe}^{++}+\mathrm{O}_{2}+10 \mathrm{H}_{2} \mathrm{O} \rightarrow 4 \mathrm{Fe}(\mathrm{OH})_{3}+8 \mathrm{H}^{+}$

Figure 13 illustrates a hypothetical biogeochemical cycle of methane and hydrogen under Archean conditions. The methane generated by methanogens was oxidized photochemically in the atmosphere to carbon dioxide and hydrogen. These products then flowed back into the ocean to be converted by biological activity into methane and water. The steady loss of hydrogen from the top of the atmosphere was balanced by the oxidation of a fraction of the flux of reduced minerals passing through the ocean in solution.

Our results, summarized in Fig. 9, allow some estimates to be made of the relative magnitudes of the fluxes and concentrations in this cycle. Suppose, for example, that the methane flux was close to the modern value, $\sim 1.5 \times$ $10^{11} \mathrm{~cm}^{-2} \mathrm{~s}^{-1}$, and that the $\mathrm{CO}_{2}$ mixing ratio was about $10 \mathrm{PAL}$. According to Fig. 9 the methane mixing ratio would have been about $3 \times 10^{-5}$. Using the piston velocity approach (Broecker, 1974) we calculate that an average supersaturation of methane in surface seawater by a factor of $\sim 3$ would have

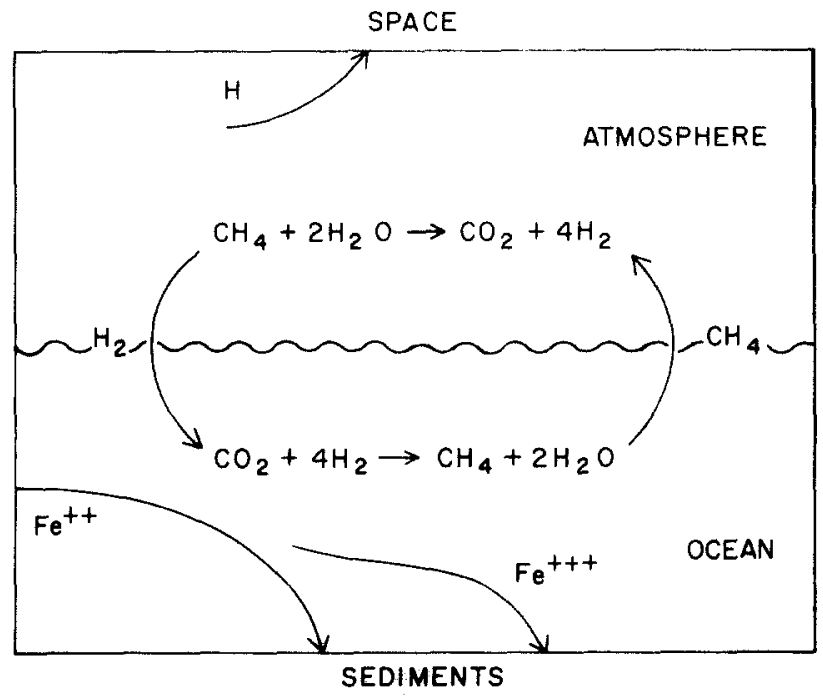

Fig. 13. Possible biogeochemical cycles of methane and hydrogen during the Archean era. 
provided the necessary flux. The return flux of hydrogen would have required an atmospheric hydrogen partial pressure larger by $5 \times 10^{-4}$ atmospheres than the partial pressure in solution equilibrium with surface seawater (Walker, $1980 \mathrm{~b}$ ). Modern methanogens can apparently hold hydrogen partial pressures down to $3 \times 10^{-4}$ atmospheres (Hungate, 1967; Wolin, 1976) and photosynthetic bacteria can probably lower hydrogen even further (Walker, 1980c), so the atmospheric partial pressure of hydrogen was not likely to have exceeded $8 \times 10^{-4}$ atmospheres.

With a hydrogen mixing ratio of $8 \times 10^{-4}$, a methane mixing ratio of $3 \times$ $10^{-5}$, and a stratospheric water vapor mixing ratio of $3.8 \times 10^{-6}$, the hydrogen escape flux would have been $10^{11}$ atoms $\mathrm{cm}^{-2} \mathrm{~s}^{-1}$ according to eq. 3 . This expression probably overestimates the escape flux at high hydrogen partial pressures (Kasting and Walker, 1981) so the required rate of supply of reducing power to atmosphere and ocean would have been smaller than $10^{11} \mathrm{~cm}^{-2} \mathrm{~s}^{-1}$. From the point of view of biogeochemical cycles we find no obvious defect in the hypothesis that methane mixing ratios exceeding $10^{-6}$ could have been sustained in the Archean atmosphere by methanogenic bacteria.

We have already noted the possible climatic impact of the greenhouse effect due to this much methane and the hydrocarbon products of its photochemical destruction. Accumulation of abundant free oxygen in the atmosphere in the Early Proterozoic may have lowered the concentrations of methane and other hydrocarbons in the atmosphere, causing a global climatic cooling (Walker et al., 1983). The Early Proterozoic glaciogenic rocks of the Huronian sequence in Canada are underlain by sedimentary rocks that appear to have been deposited under reducing conditions and are overlain by rocks that appear to have been deposited under oxidizing conditions (Roscoe, 1969, 1973).

Turning to the possible abundance of methane in the prebiological atmosphere, abiotic sources of methane are likely to have been quite small (with the possible exception of a $\mathrm{CO}$ rich atmosphere, as discussed above) after the initial period of Earth accretion, dissipation of the solar nebula, and differentiation of the Earth into core, mantle and crust. The present oxidation state of the Earth's upper mantle is such that the fraction of total carbon released as methane by volcanoes and metamorphic reactions is much less than that released as carbon dioxide or carbon monoxide. An estimate for the presentday release rate of carbon monoxide is $2 \times 10^{8}$ molecules $\mathrm{cm}^{-2} \mathrm{~s}^{-1}$ (Kasting and Walker, 1981). Thus, even if the early rate of release of volcanic and metamorphic gases were 10-100 times higher than at present, the amount of methane released is hardly likely to have been enough to maintain a methane mixing ratio as high as $10^{-6}$. Since the segregation of the core very probably occurred during the course of Earth accretion (Stevenson, 1983), there is no reason to believe that volcanic and metamorphic gases on the early Earth were richer in methane than they are today (Holland, 1962).

Mid-ocean hot springs provide a potentially important source of abiotic methane, especially in light of evidence for much stronger interaction be- 
tween seawater and mantle in the Archean (Veizer, 1976, 1979; Veizer and Jansen, 1979). The present-day rate of supply of methane by mid-ocean ridge hot springs has been estimated at $1.6 \times 10^{8} \mathrm{~m}^{3} \mathrm{y}^{-1}$ (Welhan and Craig, 1979; Craig and Lupton, 1980), equivalent to a flux of $3 \times 10^{7}$ molecules $\mathrm{cm}^{-2} \mathrm{~s}^{-1}$. Unless this mid-ocean source of methane were 1,000 times larger on the Archean Earth it could not have yielded methane mixing ratios in the atmosphere as high as $10^{-6}$. As discussed in the previous section, methane may have been generated photochemically in an atmosphere rich in $\mathrm{H}_{2} \mathrm{O}$ and $\mathrm{CO}$. The magnitude of the source will remain uncertain until more is known about the reeaction mechanisms involved.

These findings can be summarized in a very tentative history of atmospheric methane. Any primordial methane accumulated during the course of Earth accretion would have been dissipated by photochemical reactions in the atmosphere in a geologically short period of time after the segregation of the core. Abiotic sources of methane are not likely to have been large enough to sustain methane mixing ratios as high as $10^{-6}$, the threshold for a possible methane greenhouse, with a CO-rich atmosphere being a possible exception. After the origin of life an increasing biogenic source of methane may have driven methane mixing ratios well above $10^{-6}$. The rise of atmospheric oxygen in the early Proterozoic may have led to more rapid photochemical destruction of methane, lowering the methane mixing ratio to approximately its present value of $1.4 \times 10^{-6}$. Indeed, the methane mixing ratio may have dropped briefly to much lower values due to rapid photochemical oxidation processes in mildly oxidizing atmospheres (Kasting and Donahue, 1980).

\section{ACKNOWLEDGMENTS}

We would like to thank Y.L. Yung and R.E. Dickinson for valuable discussions concerning methane photochemistry and possible greenhouse effects. The National Center for Atmospheric Research is sponsored by the National Science Foundation. This research was supported in part by the National Aeronautics and Space Administration under Grant Number NAGW-176, and by the National Center for Atmospheric Research under project number 6567.

\section{REFERENCES}

Allen, M., Pinto. J.P. and Yung, Y.L., 1980. Titan: aerosol photochemistry and variations related to the sunspot cycle. Astrophys. J., 242: L125-L128.

Baker-Blocker, A., Donahue, T.M. and Mancy, K.H., 1977. Methane flux from wetland areas. Tellus, 29: 245-250.

Barassin, J. and Combourie, J., 1974. Etude cinétique des réaction entre l'oxygèn atomique et les dérivés chlorés du méthane. II. Réactions $\mathrm{CH}_{3} \mathrm{CO}+\mathrm{O}, \mathrm{CHCl}_{3}+\mathrm{O}$, $\mathrm{CCl}_{4}+\mathrm{O}$ et $\mathrm{CH}_{4}+\mathrm{O}$; resulthes experimentaux. Bull. Soc. Chim. Fr., p. 1-5.

Bar-Nun, A. and Chang, S., 1981. Photochemical reaction of carbon monoxide and water in the Earth's primitive atmosphere. J. Geophys. Res., in press. 
Baulch, D.L., Drysdale, D.D., Duxbury, J. and Grant, S.J., 1976. Evaluated Kinetic Data for High Temperature Reactions. Vol. 3, Butterworth's, London, 433 pp.

Becker, K.H., Haaks, D. and Schürgers, M., 1971. Fluorescence by the vacuum-UV photolysis of acetylene. Z. Naturforsch., 26: 1770-1771.

Bell, J.A., 1971. Methylene reaction rates. Quantum yields in the diazomethane-propane photolysis system: Effects of photolysis time, reactant ratios, and added gases. J. Phys. Chem., 75: 1537-1549.

Benson, S.W., 1964. Some problems of structure and reactivity in free radical and molecule reactions in the gas phase. Adv. Photochem., 2: 1-23.

Benson, S.W. and Haugen, G.R., 1967. The mechanisms of the high temperature reactions between $\mathrm{C}_{2} \mathrm{H}_{2}$ and hydrogen. J. Phys. Chem., 71: 4404-4411.

Bosnali, M.W. and Perner, D., 1971. Reaktionen von pulsradiolytisch erzeugtem $\mathrm{CH}\left({ }^{2} \Pi\right)$ mit Methan und anderen substanzen. Z. Naturforsch., 26a: 1768-1769.

Braun, W., Bass, A.M. and Pilling, M., 1970. Flash photolysis of ketene and diazomethane: The production and reaction kinetics of triplet and singlet methylene. J. Chem. Phys., 52: $5131-5143$.

Braun, W., McNesby, J.R. and Bass, A.M., 1967. Flash photolysis of methane in the vacuum ultraviolet. II. Absolute rate constants for reactions of $\mathrm{CH}$ with methane, hydrogen, and nitrogen. J. Chem. Phys., 46: 2071-2080.

Broecker, W.S., 1974. Chemical Oceanography. Harcourt Brace Jovanovich, New York, $214 \mathrm{pp}$.

Calvert, J.G. and Pitts, J.N., 1966. Photochemistry. Wiley, New York, 899 pp.

Calvert, J.G., Kerr, J.A., Demerjian, K.L. and McQuigg, R.D., 1972. Photolysis of formaldehyde as a hydrogen atom source in the lower atmosphere. Science, 175: 751-752.

Campbell, J.M. and Thrush, B.A., 1967. The association of oxygen atoms and their combination with nitrogen atoms. Proc. R. Soc. London, Ser. A, 296:222-232.

Cheng, J.T. and Yeh, C., 1977. Pressure dependence of the rate constant of the reaction $\mathrm{H}+\mathrm{CH}_{3} \rightarrow \mathrm{CH}_{4}$. J. Phys. Chem., 81: 1982-1984.

Craig, H. and Lupton, J.E., 1980. Helium-3 and mantle volatiles in the ocean and the oceanic crust. In: The Sea. Vol. 7, The Oceanic Lithosphere. Wiley, New York, 758 pp.

Dacey, J.W.H. and Klug, M.J., 1979. Methane flux from lake sediments through water lilies. Science, 203: 1253-1255.

Demerjian, K.L., Kerr, J.A. and Calvert, J.G., 1974. The mechanism of photochemical smog formation. In: J.N. Pitts and R.L. Metoalf (Editors), Advances in Environmental Science and Technology. Vol. 4, Wiley, New York, 382 pp.

Deuser, W.G., Degens, E.T., Harvey, G.R. and Rubin, M., 1973. Methane in Lake Kivu: new data bearing on its origin. Science, 181:51-54.

Donner, L. and Ramanathan, V., 1980. Methane and nitrous oxide: their effects on the terrestrial climate. J. Atmos. Sci., 37: 119-124.

Ehhalt, D.H. and Schmidt, U., 1978. Sources and sinks of atmospheric methane. Palaeogeogr. Palaeoclimatol. Palaeoecol., 116: 452-464.

Frakes, L.A., 1979. Climates Throughout Geologic Time. Elsevier, New York, 310 pp.

Gorden, R. and Ausloos, P., 1967. Gas-phase photolysis and radiolysis of methane. Formation of hydrogen and ethylene. J. Chem. Phys., 46: 4823-4834.

Gray, C.T. and Gest, H., 1965. Biological formation of molecular hydrogen. Science, 148: 186-192.

Hack, W., Wagner, H.G. and Hoyermann, K., 1978. Reaktionen von Wasserstoffatomen mit Hydroperoxylradikalen. I. Bestimmung der spezifischen Geschwindigkeitskonstanten der Reaktionskanäle. Ber. Bunsenges. Phys. Chem., 82: 713-719.

Hack, W., Preuss, A.W., Wagner, H.G. and Hoyermann, K., 1979. Reaktionen von Wasserstoffatomen mit Hydroperoxylradikalen. II. Bestimmung der Geschwindigkeitskonstanten der Bruttoreaktion. Ber. Bunsenges. Phys. Chem., 83: 212-217.

Hampson, R.F. and Garvin, D., 1977. Reaction Rate and Photochemical Data for Atmospheric Chemistry - 1977. Natl. Bur. Stand. Spec. Publ. No. 513, 107 pp. 
Hanel, R., Conrath, B., Flaser, F.M., Kunde, V., Maguire, W., Pearl, J., Pirraglia, J., Samuelson, R., Herath, L., Allison, M., Cruikshank, D., Gautier, D., Gierasch, P. Horn, L., Koppany, R. and Ponnamperuma, C., 1981. Infrared observations of the Saturnian system from Voyager 1. Science, 212: 192-200.

Hayes, J.M., 1983. Geochemical evidence bearing on the origin of aerobiosis, a speculative interpretation. In: J.W. Schopf (Editor), The Earth's Earliest Biosphere: Its Origin and Evolution. Princeton University Press, Princeton, NJ, 873 pp.

Huebner, W.F. and Carpenter, C.W., 1979. Solar photo rate coefficients. NASA informal report LA-8085-MS, Los Alamos, NM, 97 pp.

Hochanadel, C.J., Sworski, T.J. and Ogren, P.J., 1980. Ultraviolet spectrum and reaction kinetics of the formyl radical. J. Phys. Chem., $84: 231-235$.

Holland, H.D., 1962. Model of the evolution of the earth's atmosphere. In: A.E.J. Engle, H.L. James and B.F. Leonard (Editors), Petrologic Studies: A Volume to Honor A.E. Buddington. Geological Society of America, NY, pp. 447-477.

Holland, H.D., 1978. The Chemistry of the Atmosphere and Oceans. Wiley, New York, $351 \mathrm{pp}$.

Hungate, R.E., 1967. Hydrogen as an intermediate in the rumen fermentation. Arch. Microbiol., 59: 158-164.

Hunten, D.M., 1973. The escape of light gases from planetary atmospheres. J. Atmos. Sci., 30: 1481-1494.

Hunten, D.M., 1975. Vertical transport in atmospheres. In: B.M. McCormac (Editor), Atmospheres of Earth and Planets. D. Reidel, Dordrecht, The Netherlands, pp. 59-72.

Hunten, D.M. and Donahue, T.M., 1976. Hydrogen loss from the terrestrial planets. Annu. Rev. Earth Planet. Sci., 4: 265-292.

Jet Propulsion Laboratory, 1979. Chemical Kinetic and Photochemical Data for Use in Stratospheric Modelling. JPL Publication 79-27, Pasadena, 240 pp.

Kasting, J.F., 1982. Stability of ammonia in the primitive terrestrial atmosphere. J. Geophys. Res, 87 : 3091-3098.

Kasting, J.F. and Donahue, T.M., 1980. The evolution of atmospheric ozone. J. Geophys. Res., 85: 3255-3263.

Kasting, J.F. and Walker, J.C.G., 1981. Limits on oxygen concentration in the prebiological atmosphere and the rate of abiotic fixation of nitrogen. J. Geophys. Res., 86: 11471158.

Kasting, J.F., Liu, S.C. and Donahue, T.M., 1979. Oxygen levels in the prebiological atmosphere. J. Geophys. Res., 84: 3097-3107.

Knoll, A.H., 1979. Archean photoautotrophy: some alternatives and limits. Origin Life, 9: $313-327$.

Koblentz-Mishke, O.J., Volkovinsky, V.V. and Kabanova, J.G., 1970. Plankton primary production of the world ocean. In: W.S. Wooster (Editor), Scientific Exploration of the South Pacific. Natl. Acad. Sci, Washington, DC, $257 \mathrm{pp}$.

Koyama, T., 1963. Gaseous metabolism in lake sediments and paddy soils and the production of atmospheric methane and hydrogen. J. Geophys. Res., 68: 3971-3973.

Kuhn, W.R. and Atreya, S.K., 1979. Ammonia photolysis and the greenhouse effect in the primordial atmosphere of the Earth. Icarus, 37: 207-213.

Lasaga, A.C., Holland, H.D. and Dwyer, M.J., 1971. Primordial oil slick. Science, 174: $53-55$.

Laufer, A.H. and Bass, A.M., 1974. Rate constants for reactions of methylene with carbon monoxide, oxygen, nitric oxide and acetylene. J. Phys. Chem., 78: 1344-1348.

Laufer, A.H. and Bass, A.M., 1979. Photochemistry of acetylene. Bimolecular rate constant for the formation of butadiene and reactions of ethynyl radicals. J. Phys. Chem., 83: $310-313$.

Lee, J.T., Michaels, J.V., Payne, W.A. and Stief, L.J., 1978. Absolute rate of the reaction of atomic hydrogen with ethylene from 198 to $320 \mathrm{~K}$ at high pressure. J. Chem. Phys., 68: $1817-1820$. 
Liu, S.C. and Donahue, T.M., 1974. The aeronomy of hydrogen in the atmosphere of the Earth. J. Atmos. Sci., 31: 1118-1136.

Mount, G.H. and Moos, H.W., 1978. Photoabsorption cross sections of methane and ethane, $1380-1600 \AA$, at $\mathrm{T}=295 \mathrm{~K}$ and $\mathrm{T}=200 \mathrm{~K}$. Astrophys. J., $224: \mathrm{L} 35-\mathrm{L} 38$.

Mount, G.H., Warden, E.S. and Moos, H.W., 1977. Photoabsorption cross sections of methane from 1400 to 1850 \&. Astrophys. J., 214: L47-L49.

Nakayama, T. and Watanabe, K., 1964. Absorption and photolysis coefficients of acetylene, propyne and 1-butyne. J. Chem. Phys., 40: 558-561.

Newman, M.J. and Rood, R.T., 1977. Implications of solar evolution for the Earth's early atmosphere. Science, 198: 1035-1037.

Okabe, H. and Becker, D.A., 1963. Vacuum ultraviolet photochemistry. VII. Photolysis of n-butane. J. Chem. Phys., 39: 2549-2555.

Okabe, H. and McNesby, J.R., 1962. Vacuum ultraviolet photochemistry. IV. Photolysis of propane. J. Chem. Phys., 37: 1340-1346.

Owen, T., Cess, R.D. and Ramanathan, V., 1979. Early Earth: an enhanced carbon dioxide greenhouse to compensate for reduced solar luminosity. Nature, 277: 640-642.

Payne, W.A. and Stief, L.J., 1976. Absolute rate constant for the reaction of atomic hydrogen with acetylene over an extended pressure and temperature range. J. Chem. Phys., 64: 1150-1155.

Pilling, M.J. and Robertson, J.A., 1975. A rate constant for $\mathrm{CH}_{2}\left({ }^{3} \mathrm{~B}_{1}\right)+\mathrm{CH}_{3}$. Chem. Phys. Lett., 33: 336-339.

Pinto, J.P., Gladstone, C.R. and Yung, Y.L., 1980. Photochemical production of formaldehyde in the Earth's primitive atmosphere. Science, $210: 183-185$.

Reilly, J.P., Clark, J.H., Moore, C.B. and Pimental, G.C., 1978. HCO production, vibrational relaxation, chemical kinetics and spectroscopy following laser photolysis of formaldehyde. J. Chem. Phys., 69: 4381-4394.

Roscoe, S.M., 1969. Huronian rocks and uraniferous conglomerates in the Canadian Shield. Geol. Surv. Can. Pap. 68-40, 205 pp.

Roscoe, S.M., 1973. The Huronian supergroup, a Paleophebian succession showing evidence of atmospheric evolution. Geol. Assoc. Can. Spec. Pap. 12: 31-48.

Russell, R.L. and Rowland, F.S., 1979. Mechanism of product formation during the photolysis of ketene. J. Phys. Chem., 83: 2073-2078.

Sagan, C. and Mullen, G., 1972. Earth and Mars: Evolution of atmospheres and surface temperatures. Science, 177:52-56.

Schoell, M. and Wellmer, F.W., 1981. Anomalous ${ }^{13} \mathrm{C}$ depletion in early Precambrian graphites from Superior Province, Canada. Nature, 290: 696-699.

Stevenson, D.J., 1983. The nature of the Earth prior to the rock record (The Hadean Earth). In: J.W. Schopf (Editor), The Earth's Earliest Biosphere: Its Origin and Evolution, Princeton University Press, Princeton, NJ, 873 pp.

Stief, L.J., DeCarlo, V.J. and Mataloni, R.J., 1965. Vacuum-ultraviolet photolysis of acetylene. J. Chem. Phys., 42: 3113-3121.

Strobel, D.F., 1973. The photochemistry of hydrocarbons in the Jovian atmosphere. J. Atmos. Sci., 30: 489-498.

Takita, S., Mori, Y. and Tanaka, I., 1968. The acetylene-photosensitized reaction of methane at $1470 \AA$. J. Phys. Chem., 72: 4360-4365.

Takita, S., Mori, Y. and Tanaka, I., 1969. Acetylene photolysis at 1236 and 1470 A. J. Phys. Chem., 73: 2929-2934.

Teng, L. and Jones, W.E., 1972. Kinetics of the reactions of hydrogen atoms with ethylene and vinyl fluoride. J. Chem. Soc. Faraday Trans., 1, 68: 1267-1277.

Troe, J., 1977. Theory of thermal unimolecular reactions at low pressures. II. Strong collision rate constants. Applications. J. Chem. Phys., 66: 4758-4775.

Van den Bergh, H.E., 1976. The recombination of methyl radicals in the low pressure limit. Chem. Phys. Lett., 43: 201-204. 
Veizer, J., 1976. ${ }^{87} \mathrm{Sr} /{ }^{86} \mathrm{Sr}$ evolution of seawater during geologic history and its significance as an index of crustal evolution. In: B.F. Windley (Editor), The Early History of the Earth. Wiley, London, pp. 569-578.

Veizer, J., 1979. Secular variations in chemical composition of sediments: a review. In: L.H. Ahrens (Editor), Origin and Distribution of the Elements.. Pergamon, Oxford, pp. 269-278.

Veizer, J. and Jansen, S.L., 1979. Basement and sedimentary recycling and continental evolution. J. Geology, 87: 341-370.

Walker, J.C.G., 1977. Evolution of the Atmosphere. Macmillan, New York, 318 pp.

Walker, J.C.G., 1978. The early history of oxygen and ozone in the atmosphere. Pure Appl. Geophys., 117: 498-512.

Walker, J.C.G., 1980a. The oxygen cycle. In: O. Hutzinger (Editor), The Natural Environment and the Biogeochemical Cycles. Springer-Verlag, Berlin, pp. 87-104.

Walker, J.C.G., 1980b. The influence of life on the evolution of the atmosphere. Life Sci. Space Res., 8: 89-100.

Walker, J.C.G., 1980c. Atmospheric constraints on the evolution of metabolism. Origins Life, 10: 93-104.

Walker, J.C.G., Hays, P.B. and Kasting, J.F., 1981. A negative feedback mechanism for the long-term stabilization of Earth's surface temperature. J. Geophys. Res., 86: 97769782.

Walker, J.C.G., ,Klein, C., Schidlowski, M., Schopf, J.W., Stevenson, D.J. and Walter, M.R., 1983. Environmental evolution of the Archaean-Early Proterozoic Earth. In:

J.W. Schopf (Editor), The Earth's Earliest Biosphere: Its Origin and Evolution. Princeton University Press, Princeton, NJ, $873 \mathrm{pp}$.

Walter, M.R., Buick, R. and Dunlop, J.S.R., 1980. Stromatolites 3,400-3,500 Myr old from the North Pole era, Western Australia. Nature, 284: 443-445.

Watson, A., Lovelock, J.E. and Margulis, L., 1978. Methanogenesis, fires and the regulation of atmospheric oxygen. Biosystems, 10: 293-298.

Welhan, J.A. and Craig, H., 1979. Methane and hydrogen in East Pacific Rise hydrothermal fluids. Geophys. Res. Lett, $6: 829-831$.

Woese, C.R. and Fox, G.E., 1977. Phylogenetic structure of the prokaryotic domain: the primary kingdoms. Proc. Natl. Acad. Sci. U.S.A., 74: 5088-5090.

Wolfe, R.S., 1971. Microbial formation of methane. Adv. Microb. Physiol., 6: 107-146.

Wolin, M.J., 1976. Interactions between $\mathrm{H}_{2}$-producing and methane-producing species. In: H.G. Schlegel, G. Gottschalk and N. Pfennig (Editors), Symposium on Microbiological Production and Utilization of Gases $\left(\mathrm{H}_{2}, \mathrm{CH}_{4}, \mathrm{CO}\right)$. E. Goltzke KG, Göttingen, pp. 141-150.

Yung, Y.L., 1976. A numerical method for calculating the mean intensity in an inhomogeneous Rayleigh scattering atmosphere. J. Quant. Spectrosc. Radiat. Transfer, 16: $755-761$.

Yung, Y.L. and McElroy, M.B., 1979. Fixation of nitrogen in the prebiotic atmosphere. Science, 203: 1002-1004.

Yung, Y.L. and Pinto, J.P., 1978. Primitive atmosphere and implications for the formation of channels on Mars. Nature, 273: 730-732.

Yung, Y.L. and Strobel, D.F., 1980. Hydrocarbon photochemistry and Lyman alpha albedo of Jupiter. Astrophys. J., 239: 395-402.

Zeikus, J.G. and Winfrey, M.R., 1976. Temperature limitation of methanogenesis in aquatic sediments. Appl. Environ. Microbiol., 31: 99-107.

Zelikoff, M. and Watanabe, $K$., 1953. Absorption coefficients of ethylene in the vacuum ultraviolet. J. Opt. Soc. Am., 43: 756-759. 